\title{
Laciniporus arabicus gen. et sp. nov. (Dinophyceae, Peridiniales), a new thecate, marine, sand-dwelling dinoflagellate from the northern Indian Ocean (Arabian Sea)
}

\author{
Saburova Maria ${ }^{1,}{ }^{*}$, Chomérat Nicolas ${ }^{2}$ \\ ${ }^{1}$ Ecosystem-Based Management of Marine Resources Program, Environment and Life Sciences \\ Research Center; Kuwait Institute for Scientific Research; P.O. BOX 1638 Salmiya 22017, Kuwait \\ 2 IFREMER, LER BO; Station de Biologie Marine; Place de la Croix F-29900 Concarneau, France \\ * Corresponding author : Maria Saburova, email address : msaburova@gmail.com
}

\begin{abstract}
:
A new thecate, photosynthetic, sand-dwelling marine dinoflagellate, Laciniporus arabicus gen. et $\mathrm{sp}$. nov., is described from the subtidal sediments of the Omani coast in the Arabian Sea, northern Indian Ocean, based on detailed morphological and molecular data. Cells of $L$. arabicus are small (16.2-30.1 $\mu \mathrm{m}$ long and 13.1-23.2 $\mu \mathrm{m}$ wide), dorsoventrally compressed, with a small apical flap-shaped projection pointing to the left. The thecal plate pattern is distinguished by minute first precingular plate and sulcus, which extends into the epitheca, with large anterior and right sulcal plates. The Kofoidian thecal tabulation is Po, X, 4', 2a, 7", 6c, 6s, 5"', 2"'". Morphologically, the revealed plate pattern has an affinity to the Peridiniales, and LSU rDNA based phylogenetic analyses placed $L$. arabicus within the Thoracosphaeraceae, close to calcareous-cyst producing scrippsielloids, predatory pfiesteriaceans, and photosynthetic freshwater peridinioids Chimonodinium lomnickii and Apocalathium spp. However, the thecal plate arrangement of $L$. arabicus differs noticeably from any currently described dinoflagellates, and the species stands out from closely related taxa by extensive differences in physiology and ecology.
\end{abstract}

Keywords: Arabian Sea benthic dinoflagellates Dinophyceae, Laciniporus arabicus, molecular phylogeny, morphology, Oman, Peridiniales, taxonomy 


\section{INTRODUCTION}

Over the past decades, benthic dinoflagellates have attracted considerable research attention due to their morphological and taxonomic diversity and ecological significance in marine benthic ecosystems (e.g., Fraga et al. 2012, Hoppenrath et al. 2013, 2014). Based on recent assessments, the overall biodiversity of benthic dinoflagellates has been estimated to be in the range of approximately 160-190 species (Taylor et al. 2008, Gómez 2012, Hoppenrath et al. 2014). Recently, a high number of new dinoflagellate species have been discovered in a variety of benthic habitats along the world's coastlines (e.g., Hoppenrath et al. 2014, Hoppenrath and Elbrächter 2017). Obvious morphological characteristics of many benthic dinoflagellates (e.g., smooth and flattened cell shape and covered apical pore) seem to confer a selective advantage for sand-dwelling forms to inhabit the interstices between sediment particles and remain there when disturbed by currents or waves (e.g., Fraga et al. 2012, Hoppenrath et al. 2014, Saburova and Chomérat 2014).

Habitat-specific morphology is reflected by unusual thecal plate tabulation in many armored sand-dwelling dinoflagellate taxa when compared to planktonic species (e.g., Faust and Balech 1993, Horiguchi 1995, Murray and Patterson 2004, Hoppenrath and Selina 2006, Murray et al. 2006, Chomérat and Nézan 2009, Chomérat et al. 2010, Nézan and Chomérat 2011, Chomérat and Bilien 2014, Saburova and Chomérat 2014). The current systematic hierarchy of benthic armored dinoflagellates encompasses a wide range of monotypic genera with unique morphological characters and uncertain or unknown affiliations to higher taxa, which are morphologically and genetically distinct from any dinoflagellate genus hitherto described (e.g., Ailadinium, Amphidiniella, Herdmania, Madanidinium, Pileidinium, Plagiodinium, Planodinium, Pseudothecadinium, Rhinodinium, and Sabulodinium; Saunders and Dodge 1984, Faust and Balech 1993, Horiguchi 1995, Hoppenrath et al. 2003, Tamura and Horiguchi 2005, Hoppenrath and Selina 2006, Murray et al. 2006, Hoppenrath et al. 2007, Yamaguchi et al. 2011, Chomérat and Bilien 2014, Saburova and Chomérat 2014).

This article is protected by copyright. All rights reserved. 
The northern Indian Ocean is very poorly characterized in terms of species diversity of benthic dinoflagellates. Except for Kuwait's shore in the westernmost part of the Persian Gulf, where a long-term systematic survey has revealed a total of 60 benthic taxa (Saburova et al. 2009, 2012a, b, 2013, Al-Yamani and Saburova 2010, Chomérat et al. 2012), to date almost nothing is known about the occurrence and species composition of benthic dinoflagellates along the Arabian Sea coast. Recently, benthic dinoflagellate assemblages have been described with emphasis on ciguaterarelated species, for the central Red Sea off the Saudi Arabia coast (Catania et al. 2017), and from the northern Red Sea, the Gulf of Aqaba (Saburova et al. 2013). Benthic species of the genus Gambierdiscus have been recorded from the net phytoplankton in Pakistani coastal waters (Munir et al. 2011). Very recently, small-sized benthic Prorocentrum sipadanense was the only species revealed in occasional samples from the Omani coast (Saburova and Chomérat 2016); however, no systematic taxonomic studies of benthic dinoflagellates have been realized in Oman to date.

During recent taxonomic surveys of benthic dinoflagellates in the Middle East in Jordan (the Gulf of Aqaba, northern Red Sea) and Kuwait (northwestern Persian/Arabian Gulf), a small photosynthetic peridinioid dinoflagellate with unique morphology was recorded that cannot be associated with any currently described species. However, this dinoflagellate sporadically occurred in samples from both sites in low abundance, therefore, its morphology has not been completely described, and no molecular analysis has been performed. Recently, an abundant population of this taxon was found from samples collected at the southeastern Omani coast in the Arabian Sea. The present paper describes this new dinoflagellate that was discovered in the bottom sandy sediments in the northern Indian Ocean, on the basis of light and scanning electron microscopic observations and phylogenetic rDNA study.

This article is protected by copyright. All rights reserved. 


\section{MATERIALS AND METHODS}

\section{Sampling site}

A pilot taxonomic survey of benthic dinoflagellate assemblages was performed on the Arabian Sea coast along Dhofar Governorate of the Sultanate of Oman. The coastline of Dhofar is composed of extensive high cliffs alternating with fine-grained sand beaches. The sea surface temperature in the coastal waters of the Arabian Sea varies significantly throughout the year and is strongly influenced by Indian Ocean monsoons. During summer monsoons (June-September), water temperatures drop down to $<20^{\circ} \mathrm{C}$ due to extensive coastal upwelling, whereas for the period of winter monsoons (December-February), water temperatures are much higher with typical values ranging from 23 to $28^{\circ} \mathrm{C}$. The salinity of the surface waters is within the range of 35.3-36.7 (e.g., Chiffings 1995, Rixen et al. 2000).

Sampling

During the course of sampling along the Omani coast (Arabian Sea) samples were collected in the vicinity of Salalah City at two sampling sites (Fig. 1) on February 24-25, 2014. The first sampling site was located to the west of Salalah, near Mirbat City at $16^{\circ}=58^{\prime} 03.8^{\prime \prime} \mathrm{N}, 544^{\circ} 42^{\prime} 00.3^{\prime \prime}$ E, in a small semienclosed lagoon, where five sediment samples were collected. The second site was located to the east of Salalah at $160^{\circ} 49^{\prime} 31.6^{\prime \prime} \mathrm{N}, 53^{\circ} 42^{\prime} 14.1^{\prime \prime} \mathrm{E}$ on open ocean shore, where eight sediment samples were collected. Both sites were sampled additionally in February 2016. During sampling, water temperatures ranged between $26-27^{\circ} \mathrm{C}$ and the salinity range was $35.2-35.5$.

In addition to sampling along the Omani coast, sediment samples were collected at two sampling sites in Jordan and Kuwait (Fig. 1), from where cells similar to Omani morphotype dinoflagellates have previously been found. Jordanian specimens were obtained from the coastal area in the northern Red Sea in the Gulf of Aqaba in October 2010 and 2011 at $29^{\circ} 25^{\prime} 58^{\prime \prime} \mathrm{N}$,

This article is protected by copyright. All rights reserved. 
$34^{\circ} 58^{\prime} 26^{\prime \prime} \mathrm{E}$ from the shallow slope of the inshore fringing coral reef at water temperature and salinity ranges of $23-25^{\circ} \mathrm{C}$ and $40-41$, respectively. Specimens from the northwestern Persian Gulf were obtained from the coastal area of Qaru Island in Kuwait's offshore southern waters on July 2011 at $28^{\circ} 49^{\prime} 05^{\prime \prime} \mathrm{N}, 48^{\circ} 46^{\prime} 31^{\prime \prime} \mathrm{E}$ at the water temperature and salinity of $27^{\circ} \mathrm{C}$ and 41.2 , respectively.

At all sampling sites, bottom fine-grained sandy sediments were collected underwater, within the upper subtidal zone at depths of 1.5-3 m during snorkeling. The topmost layer of sand $(0.5-1 \mathrm{~cm})$ was scraped using a $50 \mathrm{~mL}$ Falcon tube by a diver. Water temperature and salinity were measured on-site with a field waterproof thermometer (ETI Ltd., UK) and a hand-held refractometer (Atago, Japan). Sediment samples with ambient water were kept at a temperature and illumination roughly corresponding to those of the site of collection for about one day prior to processing.

\section{Sample processing}

Sand-dwelling dinoflagellate cells were separated from the sandy sediment by extraction using the frozen seawater method (Uhlig 1964) with a $110 \mu \mathrm{m}$ mesh size. The material was initially viewed alive with a Leica DMIL inverted microscope at $35 \times$ to $200 \times$ magnifications. One replicate of each sample was preserved using 4\% Lugol's solution and examined by SEM or for molecular analysis.

\section{Isolation and culture maintenance}

Individual dinoflagellate cells were isolated from samples collected along the Omani coast using a micro-capillary pipette washing method, under an inverted microscope Leica DMIL and transferred to a 96-multiwell plate containing $350 \mu \mathrm{L}$ of sterile $\mathrm{K}$ medium without silicate (Keller and Guillard 1985, Keller et al. 1987) prepared with filter-sterilized (0.22 $\mu \mathrm{m}$, Millipore) and autoclaved seawater.

This article is protected by copyright. All rights reserved. 
Isolated cells were incubated at $23.5^{\circ} \mathrm{C}$ under $80 \mu \mathrm{mol}$ photons $\cdot \mathrm{m}^{-2} \cdot \mathrm{s}^{-1}$ of light and $12: 12 \mathrm{~h}$ light:dark photoperiod and at salinity 35 . When cell concentrations were sufficient, contaminantfree isolates with dividing and motile cells were sub-cultured in $25 \mathrm{~cm}^{2}$ tissue culture flasks containing $40 \mathrm{~mL}$ sterile $\mathrm{K}$ medium as stock cultures (strain Om-L-arabic-029, deposited in the private culture collection of the first author). Stock cultures were then incubated under the above conditions until use.

\section{Light and scanning electron microscopy}

For detailed observation, cells from either mixed natural samples or cultures were isolated by micropipetting in preparation for high-magnification photomicroscopy, and were then examined at $630 \times$ to $1000 \times$ magnification with Leica DM2500 (Leica, Wetzlar, Germany) light microscope (LM) equipped with epifluorescence (100 W short arc mercury lamp), differential interference contrast (DIC) optics, and Leica DFC320 digital camera. LM observation of thecal plate tabulation was performed on cells stained with Calcofluor White (Sigma Chemical Co.) according to the method of Fritz and Triemer (1985). To visualize nuclei, 4',6-diamidino-2-phenylindole (DAPI) fluorochrome was applied to cells fixed in $2.5 \%$ glutaraldehyde. Autofluorescence of chloroplasts was generated using an excitation wavelength of $568 \mathrm{~nm}$. Sulcal plates were examined from cells that had been swollen by hypoosmotic treatment. Live cell suspension in culture medium with a salinity of 35, was mixed 2:1 with distilled water, on a microscope slide for $20 \mathrm{~min}$, then stained with small drop of Calcofluor White and observed under UV light excitation. Swelling treatment with a saline-reduced medium enhanced visualization of sulcal plates due to flattening of the sulcal furrow.

For scanning electron microscopy (SEM), cells were preserved with Lugol's solution to a final concentration of 4\%, then were sonicated $(60 \mathrm{~Hz}, 5 \mathrm{~min})$ in a Branson 200 ultrasonic cleaning bath (Branson Ultrasonics, USA) to remove the outer membranes and collected on a $5-\mu \mathrm{m}$ polycarbonate membrane filter (Whatman Nucleopore Track-Etch), rinsed twice with deionized water and gradually 
dehydrated with increasing concentrations of ethanol $(15,30,50,70,90,95$ and $100 \%)$. Filters were critical point dried using Leica EM CPD300 automated critical point dryer, sputter-coated with goldpalladium using Jeol JEC-3000FC auto fine coater, and examined either by Tescan Vega3 or by LEO Supra 50VP scanning electron microscopes with an electron acceleration of $5 \mathrm{kV}$. Alternatively, cells were prepared according to Chomérat and Couté (2008) and examined using a Quanta 200 (FEI, Eindhoven, the Netherlands) SEM. The SEM photographs were presented on a uniform background using Adobe Photoshop CS2, v. 9.0.2 (Adobe Systems, San Jose, CA, USA).

Both live and preserved cells from Omani field samples and material from established cultures were examined. Additionally, field-collected specimens obtained from the northern Red Sea, the Gulf of Aqaba (Jordan) and from the northwestern Persian Gulf (Kuwait) were included in our analysis as supplementary information.

Morphometric measurements were made either from the calibrated digital LM images using Leica Application Suite v. 3.7 software (Leica Microsystems Ltd, Switzerland) or were calculated from SEM micrographs. In the Omani strain, cell dimensions were measured of 48 field-collected specimens and of 37 cultured cells. Dimensions are given as the mean \pm standard deviation. To describe the thecal plate tabulation, the nomenclature of Kofoid $(1909,1911)$ was used.

\section{DNA amplification and sequencing}

Two to three cells from the culture (strain Om-L-arabic-029 isolated from bottom sediments of the Arabian Sea coast to the eastward of Salalah City, Dhofar Governorate, the Sultanate of Oman) were isolated with a micropipette under an inverted microscope (Olympus IX51, Tokyo, Japan), rinsed in drops of $\mathrm{K}$ medium, and then placed into $0.2 \mathrm{~mL}$ PCR tubes containing about $3 \mu \mathrm{L}$ of double-distilled water. Additionally, cells from the tubes were stored at $-20^{\circ} \mathrm{C}$ until amplification. For PCR reaction, tubes were thawed and PCR Master Mix (Promega, Madison, WI, USA) and 25 pmol of each primer 
were added, as described previously in Nézan et al. (2012). PCR products were purified using the Wizard SV Gel and PCR Clean-up system (Promega) according to the manufacturer's recommendations. Sequencing was realized using an ABI PRISM Big Dye Terminator Cycle kit (Life Technologies, Carlsbad, CA, USA) and the purification kit Montage SEQ Sequencing Reaction Cleanup (Millipore, Billerica, MA, USA). Sequences were determined with an automated 3130 genetic analyzer (Applied Biosystems, Carlsbad, CA, USA).

\section{Phylogenetic analyses}

Phylogenetic analyses were realized separately for small and large ribosomal DNA. The SSU sequence of Laciniporus arabicus was aligned together with 81 sequences of dinoflagellates retrieved from GenBank (Amoebophrya sp. as outgroup) using Clustal Omega (Sievers et al. 2014) v.1.2. The final SSU alignment comprised 82 sequences and 1743 characters. The LSU sequence of $L$. arabicus was aligned together with 51 LSU sequences of dinoflagellate species, including Triadinium polyedricum (as outgroup) retrieved from GenBank using MAFFT software version 7 with Q-ins-I strategy (Katoh and Standley 2013). Subsequently, the remaining ambiguous positions in the LSU (in the D2 domain) were removed using Gblocks software (Talavera and Castresana 2007), and the final LSU data matrix comprised 52 LSU sequences and 827 aligned characters. Both alignments were refined by eye.

The two data matrices were analyzed by two methods of phylogenetic reconstruction: maximum likelihood (ML), using PhyML v. 3.0 software (Guindon et al. 2010) and Bayesian inference (BI) using MrBayes v. 3.1.2 (Ronquist and Huelsenbeck 2003). The software jModeltest v. 0.1.1 (Posada 2008) was first used to select the most suitable model of substitutions. For SSU alignment, a General Time Reversible model with invariant sites and a gamma correction for among-site rate variation was chosen $($ GTR $+I+\Gamma$ ), while for LSU rDNA alignment, the Tamura-Nei (TN93) model with 
invariant sites and a gamma correction for among-site rate variation was chosen. Bootstrap values (support for branches) of trees were obtained after 100 iterations in ML. For Bayesian inference, four Markov chains were run simultaneously for $2 \times 10^{6}$ generations with sampling every 100 generations. On the $2 \times 10^{4}$ trees obtained, the first 2000 were discarded (burn-in) and a consensus tree was constructed from the remaining trees. The posterior probabilities corresponding to the frequency, with which a node is present in preserved trees, were calculated using a coupled Monte Carlo Metropolis approach - Markov Chain (MCMC).

\section{RESULTS}

Description

Laciniporus Saburova et Chomérat gen. nov.

Solitary, marine and sand-dwelling dinoflagellates with a delicate theca. Plate formula: Po, X, 4', 2a, $7^{\prime \prime}, 6 c, 6 s, 5^{\prime \prime \prime}, 2^{\prime \prime \prime \prime}$. Epitheca and hypotheca of nearly same size; cell dorsoventrally compressed. Small apical flap-shaped projection pointing to the left cell side. First precingular plate minute. Cingulum almost median, slightly descending. Sulcus extends into the epitheca, reaching the antapex; anterior and right sulcal plates large.

Type species: Laciniporus arabicus Saburova et Chomérat sp. nov., designed here.

Etymology: From Latin lacinia $=$ flap and porus = opening or pore; referring to a small flap-shaped apical projection arising from the edge of fourth apical plate and covering the apical pore.

This article is protected by copyright. All rights reserved. 
Laciniporus arabicus Saburova et Chomérat sp. nov. (Figs. 2-8)

Holotype: the SEM stub containing the type material isolated from bottom sediments collected 24 February 2014 to the eastward of Salalah City, Oman, Arabian Sea, deposited at the dinoflagellate type collection in the Centre of Excellence for Dinophyte Taxonomy (CEDiT, Wilhelmshaven, Germany), which is part of the Herbarium Senckenbergianum Frankfurt/M. (FR), with the accession number CEDiT2018H73. A typical specimen in ventral view is illustrated in Figure 4a. Figures 4, b, d, and $f$ and $5, d$ and e illustrate other specimens from this stub.

Isotypes: Lugol fixed culture (strain Om-L-arabic-029) deposited at the dinoflagellate type collection in the Centre of Excellence for Dinophyte Taxonomy (CEDiT), Wilhelmshaven, Germany (accession number CEDiT2018174).

Additional strain materials: Living cultures of strain Om-L-arabic-029 are deposited at the private culture collection of the first author. Sequences \# MH029284 (SSU rDNA) and \# MH029283 (LSU rDNA) were obtained from this culture and deposited in GenBank.

Habitat: Marine, sand-dwelling, subtidal.

Type locality: Subtidal sandy sediments of the Arabian Sea coast to the east of Salalah City at $16{ }^{\circ} 49^{\prime} 31.6^{\prime \prime} \mathrm{N}, 53042^{\prime} 14.1^{\prime \prime} \mathrm{E}$ (Dhofar Governorate, the Sultanate of Oman).

This article is protected by copyright. All rights reserved. 
Etymology: The specific epithet refers to the geographical area (Arabian Peninsula), around which the species was found.

\section{Description:}

Cells are approximately oval in ventral view (Figs. 2, b, c, and g; 3, a, i, and j; 4a; 6, a and b; 8a) and dorsoventrally flattened (Figs. 3, b and c; 4, c, d, e, and g; 5a; 8, c and d), 16.2-30.1 $\mu \mathrm{m}$ long (22.12 $\pm 2.77, \mathrm{n}=47), 13.1-23.2 \mu \mathrm{m}$ wide $(17.59 \pm 2.35, \mathrm{n}=44)$, and about 9.9-13.9 $\mu \mathrm{m}$ deep, with a length/width ratio of 1.07-1.40 $(1.26 \pm 0.07, \mathrm{n}=42)$. The epitheca and hypotheca are approximately the same height. A small distinct apical flap-shaped projection (about $1.5 \mu \mathrm{m}$ in length) points to the left lateral side of the cell (Figs. 2, b, c, e, g and k; 4, a-c; 5, a-c; 6, a-d; 8, a-c). The cingulum is almost median, about 2.9-3.1 $\mu \mathrm{m}$ wide, and slightly descending at about half a cingular width (Figs. 3, a, i and j; 4a; 5e; 6e; 8a). The sulcus extends into the epitheca, slightly deflects to the right, and reaches the antapex (Figs. 3, a and i-l; 4, a and d-f; 5, e and f; 6e; 8, a and e). A large, round dinokaryon with distinct condensed chromosomes is located in the dorsal side of the hypotheca (Figs. 2, c and h; 6d; 7a). The single large pyrenoid with ring-like starch sheaths is located in the dorsal side of the epitheca (Figs. 2, d, e and g; 6d). Golden-brown branched chloroplast lobes radiate from the pyrenoid to the cell periphery, probably representing a single chloroplast network (Figs. 2, i and j). The cytoplasm contains colourless granules and sometimes red or brown accumulation bodies (Figs. 2, a and c). A large pusule is often located on the right in the ventral cell half (Fig. 2b). The transverse flagellum runs inside the cingulum around the entire circumference of the cell (Fig. 5d). The longitudinal flagellum arises in the median part of the sulcus, and is longer than the cell (Figs. $2 \mathrm{~g}$, $5 d)$. 
The plate formula is Po, $X, 4^{\prime}, 2 a, 7^{\prime \prime}, 6 c, 6 s, 5^{\prime \prime \prime}, 2^{\prime \prime \prime \prime}$. The plate arrangement of the epitheca is asymmetrical. The epitheca consists of 15 plates (Figs. 3, a-f; 4, a-e; 5a-c; 8, a-c). The almost circular apical pore plate $(\mathrm{Po})$ is encircled by four apical plates, of which the first apical plate is in contact with the sulcus and connected to the apical pore plate by the canal plate (X). The inner margin of the fourth apical plate adjoining the apical pore plate develops a thickened rim that forms a small apical flap-shaped projection. This projection partially covers the Po plate and hides the apical pore (Figs. $2 k ; 3, b$ and $c ; 4 c ; 5, a-c ; 8 c)$. The canal plate $(X)$ is small, with an elongate, rectangular outline, and is situated between Po, $1^{\prime}, 2^{\prime}$ and $4^{\prime}$ on the ventral side of the cell (Figs. 3, $d$ and e; 5, a-c; 8, a and c). The apical pore plate and canal plate complex is placed deeper with respect to the plates surrounding it (Figs. 2k, 4c, 5, a-c).

The first apical plate $\left(1^{\prime}\right)$ is large, irregularly-shaped and an asymmetric heptagon. Plate $2^{\prime}$ is hexagonal, and $3^{\prime}$ and $4^{\prime}$ are pentagonal (Figs. 3, a-e, 4, a and c-e, 5, a and b, 8, a and c). The two anterior intercalary plates are hexagonal and unequal in size. The first anterior intercalary plate (1a) is relatively small and located at the left lateral side of the epitheca, in contact with the second intercalary plate. The second anterior intercalary plate (2a) is large and transversely elongated along the dorsal side of the epitheca (Figs. 3, b, d and f, 4, b and c, 5a, 8, b and c). The precingular series consists of seven plates $\left(1^{\prime \prime}-7^{\prime \prime}\right)$, which vary in shape and size. The first precingular plate $\left(1^{\prime \prime}\right)$ is cuneate and much smaller in size compared to other precingular plates (Figs. 3, a and i, 4, a and c, 5, e and $\mathrm{f}, 8, \mathrm{a}$ and $\mathrm{c}$ ). Plate $2^{\prime \prime}$ is hexagonal, $3^{\prime \prime}$ and $5^{\prime \prime}$ are tetragonal, and $4^{\prime \prime}, 6^{\prime \prime}$, and $7 "$ are pentagonal. The plates $1^{\prime \prime}, 2^{\prime \prime}$ and $7^{\prime \prime}$ form the ventral part of the epitheca together with the $1^{\prime}$ plate, while plates $3^{\prime \prime}-6$ " are located on the dorsal side of the epitheca (Figs. 3, a, b, d, f and i, 4, a-e, 8, a-c).

The cingulum consists of six unequal plates $(1 c-6 c)$, which are irregularly disposed with the postcingular plates (Figs. 3, a, f, i and h, 4, a, b, $d$ and e, 8, a and b). The narrow first cingular plate contacts the sulcus and is of a nearly similar width to the small first precingular plate (1"). The

This article is protected by copyright. All rights reserved. 
sutures of the $1 \mathrm{c}-4 \mathrm{c}$ plates are collinear with those of the precingular plates, while the suture between $5 c$ and $6 c$ occurs in the middle of the sixth precingular plate.

The sulcal area is large and mostly flat except for a deep, narrow furrow lying obliquely along the right lateral side of the first postcingular plate ( $1^{\prime \prime \prime} ;$ Figs. 3 , a and i, 4 , a and d-f, 5, e and f, 6e, $8 a$ ). The sulcus consists of six plates (Figs. 3, a and i-I, 4, a and d, 5, e and f, 8e). The anterior sulcal plate (Sa) is large, pentagonal, and extends into the epitheca between $1^{\prime}, 1^{\prime \prime}$ and $7^{\prime \prime}$ plates. The right sulcal plate (Sd) is large, irregularly hexagonal and slightly elongated. The Sd plate is located posterior to Sa touching the lower left corner of the seventh precingular plate $\left(7^{\prime \prime}\right)$, the left side of the $6 c$ and $5^{\prime \prime \prime}$ plates, and the upper right side of the posterior sulcal plate (Sp). The left lateral margins of the Sa and Sd plates are bordered by a well-developed sulcal list (sl) or fin, which begins to rise at the lower left side of the Sa and continues along the left side of the Sd. The suture between the Sa and Sd plates is collinear with the junction between the upper and lower part of this list. In intact specimens, this list completely covers the sulcal furrow and hides the middle part of the sulcus (Figs. $3 a, 4, a$ and $d-f, 5 e, 6 e)$, but the composition of this region is discerned in thecae of osmotically swollen cells (Fig. 3, i-I). The deeply excavated sulcal furrow is formed by three plates. The narrow, elongated left sulcal plate (Ss) lies obliquely along the left lateral sides of the Sa and Sd plates and adjacent to the upper part of the first postcingular plate $\left(1^{\prime \prime \prime}\right)$, touching the upper right side of the first cingular plate (1c) and the top of posterior sulcal plate (Sp; Figs. 3, i-l, 8e). Additionally, in the inner sulcal area there are two small accessory platelets lying adjacent to the insertion points of the transverse and longitudinal flagella that are interpreted here as the anterior flagellar pore plate (afp) and posterior flagellar pore plate (pfp; Figs. 3, j-I, 8e). The afp plate adjoins the anterior part of the Ss, the right side of the $1 \mathrm{c}$ and the posterior margin of the Sa. The pfp plate lies between posterior parts of the Sd and Ss and adjacent to the Sp. The posterior sulcal plate (Sp) is relatively large, asymmetrically polygonal and extends along the lateral sides of the $1^{\prime \prime \prime}$ and $5^{\prime \prime \prime}$ plates toward the antapex (Figs. 3, a and g-l, 4, a and d-f, 5e, 8, a and e).

This article is protected by copyright. All rights reserved. 
The hypotheca consists of five postcingular $\left(1^{\prime \prime \prime}-5^{\prime \prime \prime}\right)$ and two antapical plates $\left(1^{\prime \prime \prime \prime}\right.$ and $\left.2^{\prime \prime \prime \prime}\right)$. The first (1"') and fifth ( $\left.5^{\prime \prime \prime}\right)$ postcingular plates elongate along the sulcus, occupying nearly the entire ventral side of the hypotheca (Figs. 3, a, g and i, 4, a and c-f, 5e, 8, a and d), whereas the plates $2^{\prime \prime \prime}, 3^{\prime \prime \prime}$ and $4^{\prime \prime \prime}$ together with the two antapical plates are located dorsally (Figs. 3, f and g, 4, $b, f$ and $g, 8, b$ and $d)$.

The thecal surface is smooth and covered with scattered round pores of two different sizes, minute pores (0.04-0.06 $\mu \mathrm{m}$ in diameter) and larger pores (0.13-0.16 $\mu \mathrm{m}$ in diameter; Fig. $5 \mathrm{c})$.

Densely lying larger pores form distinct marginal rows along the upper and lower edges of the postand precingular plates bordering the cingulum and along the sulcal list in the anterior sulcal plate (Figs. 4, a, b and e, 5e, 6e). The cingular and sulcal plates are smooth, except for the surface of the Sa, Sd and Sp plates with a distinctive pore arrangement (Figs. 4, a and d, 5e, 6e).

Apart from the type locality in Oman, specimens collected at geographically distant localities were assigned to the newly described Laciniporus arabicus on the basis of morphological similarity. The morphologies of specimens obtained from the northern Red Sea, Jordan (Fig. 6, a-c) and from the northwestern Persian Gulf, Kuwait (Fig. 6, d-f) were nearly identical to Omani strain with respect to size, shape, presence of apical flap-shaped projection, chloroplasts and pyrenoid arrangement, and pattern of thecal plates. Variability of thecal surface ornamentation was found by SEM in Jordanian specimens with finely reticulated thecal surface (Fig. 6c) compared to smooth theca in Omani (Figs. 4 and 5) and Kuwaiti (Fig. 6f) strains.

\section{Known distribution and occurrence}

During the present study, an abundant population of Laciniporus arabicus was found from the Omani coast of the Arabian Sea in the vicinity of Salalah City. Morphologically similar specimens have been sporadically recorded from the Jordanian coast, the Gulf of Aqaba, northern Red Sea and 
from Kuwait's bottom sediments (northwestern Persian Gulf) in low abundances in comparison with many other sand-dwelling dinoflagellates at these sampling sites (Fig. 1). Throughout all examined sampling sites, L. arabicus was observed in subtidal sandy sediments exclusively.

Life cycle in culture

In cultured strain of Laciniporus arabicus (Om-L-arabic-029), cell divisions take place when they attached themselves at the bottom of cultural flasks to form non-motile short-term thin-walled division cysts. The vegetative motile cells increase in size and sink to the bottom (right-hand cell in Fig. 7a). Round, large-sized non-motile cells represent the early division cyst stages and range in size from 30.3 to $39.2 \mu \mathrm{m}$ in length $(35.05 \pm 2.47, \mathrm{n}=10)$, and from 27.1 to $36.2 \mu \mathrm{m}$ in width $(30.44 \pm 2.89$, $\mathrm{n}=10)$. These cells are darker than motile vegetative cells and densely filled with large droplets, presumably representing reserve material (Fig. 7, a and b). Epifluorescence microscopy observation indicates the presence of an intact chloroplast and nucleus migrated from the hyposome to the cell centre (Fig. 7c). At a further stage of cyst development, the cell sheds its theca (Fig. 7, $d$ and e), forming an elliptical division cyst with a thin outer pellicular layer that appears to be smooth in LM (Fig. 7f). In this envelope, the cell undergoes binary fission; karyokinesis (Fig. 7, g-i) is followed by protoplast division (Fig. 7j). At the late stage of cytoplasmic cleavage, the protoplast escapes from the mother division cyst and finally yields two small thinly thecate motile cells (Fig. 7, k-n). Extensive formation of division cysts was observed in the dark.

Apart from short-term thin-walled division cysts, abundant thick-walled resting cysts are observed in aging cultures. These cysts are oblong in outline, 20.5-32.7 $\mu \mathrm{m}$ long $(26.09 \pm 3.10, n=11)$, and 16.0-23.5 $\mu \mathrm{m}$ wide $(19.92 \pm 2.16, \mathrm{n}=11)$. Cyst content is highly granular, almost colourless, typically with a single conspicuous orange-red accumulation body (Fig. 7o). Epifluorescence microscopy indicates the residual chlorophyll (Fig. 7p). The cyst wall is thick, double-layered, and 
non-calcareous. In the mature resting cyst, the wall surface is covered with short hair-like spines and often has an outer mucilaginous coating (Fig. 7, q and r). Most of these cysts remain viable for at least 4-5 weeks in nutrient-depleted conditions, and germinate within 1-2 d when placed in fresh replete medium.

Sequence analysis and molecular phylogeny

Sequences of SSU rDNA and LSU rDNA were acquired from a clonal strain of Laciniporus arabicus originating from the type locality (south Oman). In the SSU rDNA based phylogenies, the position of L. arabicus appeared to be very unstable and owing to the lack of statistical support of the branch, it was not possible to identify a clear relationship with other dinoflagellate taxa (Fig. S1 in the Supporting Information). However, the LSU rDNA based phylogenetic analysis (Fig. 9) showed that $L$. arabicus clustered in the clade formed by members of the family Thoracosphaeraceae with a high support (bootstrap value 95 in ML and PP 1.0 in $\mathrm{BI}$ ), indicating the probable appurtenance of this new genus to that family. Nevertheless, its position was not resolved (polytomy) within this clade. It was not clearly related to the clade containing the scrippsielloid dinoflagellates (Calciodinellum operosum, Naiadinium polonicum, Scrippsiella spp., and Theleodinium calcisporum) and parasitic Duboscquodinium collinii nor with the moderately supported (BS 87, PP 0.99) clade containing the pfiesteriaceans (Aduncodinium glandula, Pfiesteria piscicida, Luciella masanensis, and Stoeckeria algicida), the freshwater peridinioids Chimonodinium lomnickii, Apocalathium spp. and the coccoid species Thoracosphaera heimii. Other peridinioid taxa included in the analysis were distantly related to Laciniporus arabicus, and these relationships were weakly supported (Fig. 9).

This article is protected by copyright. All rights reserved. 


\section{DISCUSSION}

In the present study, a new photosynthetic sand-dwelling dinoflagellate genus and species,

Laciniporus arabicus, from the southern Omani coast, northern Indian Ocean, Arabian Sea was established. The Kofoidian plate tabulation for the genus, $\mathrm{Po}, \mathrm{X}, 4^{\prime}, 2 \mathrm{a}, 7^{\prime \prime}, 6 \mathrm{c}, 6 \mathrm{~s}, 5^{\prime \prime \prime}, 0 \mathrm{p}$, and $2^{\prime \prime \prime \prime}$, is common to most of peridinioid dinoflagellates (Fensome et al. 1993). The thecal morphology of $L$. arabicus is consistent with assignment of the species within the order Peridiniales with respect to its symmetrical hypothecal plate tabulation, possessing two equal antapical plates, and presence of small canal plate $\mathrm{X}$ in the composition of apical pore complex. Molecular data also confirmed that this new genus is related to Peridiniales.

The epithecal morphology of L. arabicus differs from other dinoflagellates most particularly in its first precingular plate $\left(1^{\prime \prime}\right)$ reduced in size, which makes the $1^{\prime}$ plate contiguous with the first two precingulars together on the left side and creates a strong asymmetric aspect to the ventral epithecal plate pattern. In association with this asymmetry, the first apical plate is irregularly polygonal and adjacent to the last apical and precingular plates on the right, and to the $2^{\prime}, 1^{\prime \prime}$, and $2^{\prime \prime}$ on the left. An asymmetrical shape of the first apical plate is a characteristic feature for the group of species within marine planktonic genus Protoperidinium Bergh with 'meta'-type of the ventral plate arrangement (e.g., Balech 1974, Abé 1981). However, photosynthetic sand-dwelling L. arabicus differs essentially from this group of Protoperidinium taxa in possessing two rather than three anterior intercalary plates and six rather than four cingular plates (Table 1). A similar asymmetrical epithecal plate arrangement has been reported in a few representatives of the genus Amphidiniopsis, in which the left side of the first apical plate contacts directly the two first precingular plates in like manner, including marine sand-dwelling $A$. aculeata (Hoppenrath et al. 2009), and A. konovalovae (Selina and Hoppenrath 2013). Nevertheless, these Amphidiniopsis species notably differ from L. arabicus in the small size of the epitheca, the number of anterior intercalary and precingular plates (A. arenaria), the cingular (in A. aculeata and A. konovalovae) and

This article is protected by copyright. All rights reserved. 
sulcal plates, and the absence of chloroplasts (Table 1). Among gonyaulacoid dinoflagellates, the small-sized sand-dwelling Amphidiniella sedentaria is the only one that possesses a similar asymmetrical epithecal plate pattern, but it differs dramatically from L. arabicus in having a single anterior intercalary plate, the absence of canal plate $\mathrm{X}$, and in cingular, sulcal and hypothecal plate arrangement (Horiguchi 1995).

The small epithecal plate at the beginning of the precingular series has been interpreted as a type of plate other than a precingular plate in some dinoflagellates of different phylogenetic origins, for instance, as an anterior sulcal plate Sa extending into the epitheca in the case of Rhinodinium broomeense (Murray et al. 2006) and in some freshwater Peridinium species including $P$. bipes, $P$. cinctum, P. volzii (Boltovskoy 1999, Hansen and Flaim 2007) or as a Z plate in Sphaerodinium cracoviense (Craveiro et al. 2010). However, in the case of L. arabicus, this plate was attributed to the precingular series rather than the sulcal group due to its location immediately anterior to the cingulum and in the same plane with other precingulars, and the same ornamentation, a marginal row of pores along the lower edge as the other precingular plates. Additionally, the small first precingular plate in L. arabicus is clearly separated from the sulcus by the raised upper cingular edge, with the suture between 1 " and 2 " plates in the epitheca corresponding to the first intercingular suture between the $1 \mathrm{c}$ and $2 \mathrm{c}$ plates.

The general morphology of L. arabicus most closely corresponds to some species in the genus Durinskia that also possess seven plates in precingular series (Table 1). L. arabicus is morphologically very similar to marine sand-dwelling $D$. agilis in average size, shape and cell compression, in presence of an apical hook and a delicate theca, in size and position of two unequal intercalary plates, and tabulation of the main thecal plate series (Saburova et al. 2012a). The thecal plate arrangement of $L$. arabicus is also similar to those described in some strains of $D$. baltica with seven precingular plates from Australian marine sediments (Murray 2003) and intertidal flats in the White Sea (Azovsky et al. 2013). Laciniporus arabicus is distinguished from Durinskia species by the

This article is protected by copyright. All rights reserved. 
shape of the first apical plate (meta- versus ortho-type); the tiny size of the first precingular plate resulting in different arrangement of the ventral plate pattern; in possessing six rather than five cingular plates; in a much larger sulcal area with the anterior sulcal plate that extends into the epitheca; in the composition of the apical pore complex with distinct flap-like projection; in possessing a single dinokaryon compared to binucleate diatom-harbouring Durinskia species; and finally, in lacking an eyespot. Moreover, the molecular phylogenetic analysis clearly showed that $L$. arabicus is only distantly related to species within the genus Durinskia (Fig. 9).

Laciniporus arabicus, marine heterotrophic dinoflagellates of the genus Stoeckeria, and freshwater photosynthetic species of the genera Naiadinium, Parvodinium, and Theleodinium share a common tabulation for the main plate series, 4', 2a, 7", 6c, 5"', $2^{\prime \prime \prime \prime}$ (Carty 2008, Craveiro et al. 2013, 2015, Jeong et al. 2014). Despite their identical plate tabulation, L. arabicus differs from Stoeckeria in possessing an apical hook and chloroplast, and from both Stoeckeria and Theleodinium in lacking a cover plate in its apical pore complex and a peduncle in its sulcal area. Additionally, the new species is distinguished from the species of freshwater photosynthetic genera Naiadinium, Parvodinium, and Theleodinium in number and composition of sulcal plates and different habitat (Table 1).

Rather similar to L. arabicus thecal plate tabulations (one plate difference) have been reported in Kryptoperidinium foliaceum (Kempton et al. 2002, Saburova et al. 2012b), Herdmania litoralis (Yamaguchi et al. 2011), Chimonodinium lomnickii (Craveiro et al. 2011), Aduncodinium glandula (Kang et al. 2015), in species of the genera Archaeperidinium (Yamaguchi et al. 2011), Luciella (Mason et al. 2007), Scrippsiella (Janofske 2000), and Apocalathium (Larsen et al. 1995, Annenkova et al. 2015, Craveiro et al. 2016; Table 1). Although infraspecific variability in epithecal plate patterns and some deviations from the typical plate formula have been reported in a range of peridinioid species (e.g., Larsen et al. 1995, Kempton et al. 2002, Yamaguchi et al. 2011, Craveiro et al. 2013, 2015), one plate difference was considered sufficient to warrant a separate genus in some

This article is protected by copyright. All rights reserved. 
peridinioid groups (e.g. in diplopsalioideans; Abé 1981, Dodge and Hermes 1981, Liu et al. 2015) or in the Pfiesteria-like group (e.g., Litaker et al. 2005, Mason et al. 2007).

The plate arrangement of the cingular and sulcal furrows are generally regarded as conservative features in thecate dinoflagellates. The number, shape and arrangement of the cingular and sulcal plates have been considered as valuable characters for the taxonomy of peridinioid taxa (e.g., Balech 1974, 1980, Abé 1981). A relatively small sulcal area composed of tiny platelets often overlying each other is commonly the most technically challenging to discern compared to other areas of the theca. The sulcal area of Laciniporus arabicus is large and mostly flat except for a deep innermost groove that almost completely hidden behind a prominent sulcal list and is only visible in Calcofluor stained thecae of osmotically swollen cells by LM (Fig. 3 i-I). Four larger plates occupy the anterior (Sa), left (Sd), right (Ss) and posterior (Sp) parts of the sulcal area. Both ends of the Ss seem to be adjacent to the flagellar pores. Both the upper transverse and lower longitudinal flagellar pores are associated with small platelets (termed here the anterior (afp) and posterior ( $p f p$ ) flagellar pore plates). The distinctive feature of $L$. arabicus is a complex sulcal list composed of the projections along Sa and Sd conjunct by suture. The suture between Sa and Sd is collinear with that of the sulcal list.

A nearly identical structure of the sulcal area, with same number of sulcal plates and arrangement, has been reported in Scrippsiella trochoidea (Janofske 2000, Hameed and Saburova 2015) and S. regalis (Janofske 2000) described as possessing six sulcal plates (Table 1), although there are some Scrippsiella species described with $5 \mathrm{~s}$ or $4 \mathrm{~s}$ and most probably with omitted internal small platelets. A distinctive character of Scrippsiella sulcus is that the Sp touches the cingulum (Steidinger and Tangen 1997), whereas this is not the case in L. arabicus. A very similar sulcal morphology to that observed in L. arabicus was also found in genera within the pfiesteriaceans, including Luciella, Pfiesteria, Pseudopfiesteria, Stoeckeria, and Tyrannodinium (Table 1), if the specific to pfiesteriaceans peduncle cover plate (PC) is interpreted as a Sd plate. However, the sulcus 
of photosynthetic L. arabicus differs notably from those described in predatory pfiesteriaceans by the lack of a special feeding tube (peduncle). Furthermore, species of the genus Apocalathium with 4-7s (Annenkova et al. 2015, Craveiro et al. 2016) were all found to possess a general composition of the sulcus similar to L. arabicus (Rengefors and Meyer 1998, Annenkova et al. 2015, Craveiro et al. 2016), although the difficulties in visualizing the minute plates within the innermost sulcal area may result in the reported variability in the number of sulcal plates. The sulcal structure was described only from A. malmogiense (syn. Scrippsiella hangoei) in enough detail for comparison with $L$. arabicus (Larsen et al. 1995). Our molecular phylogenetic data support the taxonomic significance of the cingular and sulcal morphologies in the peridinioids. All the species closely related to L. arabicus (Fig. 9) are characterized by six cingular plates and a nearly identical number and arrangement of sulcal plates (Table 1).

The conspicuous apical hook pointing to the left is a characteristic feature of $L$. arabicus shared with a range of benthic dinoflagellates. The apical pore bordered on the right side by more or less projected edge of the adjacent apical plate was reported in Aduncodinium glandula (Kang et al. 2015), Durinskia agilis (Saburova et al. 2012a), Herdmania litoralis (Yamaguchi et al. 2011), Katodinium asymmetricum, in species of the genera Coolia (Leaw et al. 2010, Jeong et al. 2012) and Ostreopsis (Kang et al. 2013), and in some Amphidiniopsis species including A. cristata, A. elongata, A. hoppenrathae, A. korewalensis, A. pectinaria and A. uroensis (Hoppenrath 2000a, b, Murray and Patterson 2002, Toriumi et al. 2002, Selina and Morozova 2017). In contrast, an apical projection pointing to the right was described in Amphidiniella sedentaria (Horiguchi 1995) and Roscoffia minor, whereas dorsally pointed apical hook was found in Rhinodinium broomeense (Horiguchi and Kubo 1997, Murray et al. 2006). The apical hook in L. arabicus is most similar to those described in Herdmania litoralis and Amphidiniopsis species, but the new species differs significantly by its thecal plate pattern and the presence of chloroplast (Table 1).

This article is protected by copyright. All rights reserved. 
The life style, within interstitial spaces of marine sediments, differs radically from that in water column resulting in remarkable morphological diversity of sand-dwelling dinoflagellates. Many of them are characterized by unusual morphologies when compared to the plankton species and appear to be adapted to a benthic environment in their specific morphological features and behaviour (Fraga et al. 2012, Hoppenrath et al. 2014). The function of an apical hook-shaped projection that partially covers an apical pore in many sand-dwelling dinoflagellates has not yet been elucidated (Hoppenrath et al. 2014, Kang et al. 2015), although its role in protecting the apical pore has been hypothesized (Hoppenrath et al. 2014), and the presence of a large chamber beneath the apical hook has been revealed in Aduncodinium glandula (Kang et al. 2015). The involvement of an apical pore in the formation of a mucilage apical stalk to anchor the cells to the substrate has been shown for some benthic dinoflagellates including Stylodinium littorale, Scrippsiella hexapraecingula (Horiguchi and Chihara 1983a, b), and Bysmatrum arenicola (Horiguchi and Pienaar 1988). We speculate that the apical projection partially covering the apical pore may serve as a means to increase the pressure and setting the direction of the ejected mucilage from the apical pore (by analogy with nozzle on a garden hose), which ensures the rapid and durable adhesion of cells to the substrate, enabling them to withstand hydrodynamic disturbances, and protecting them from detachment and resuspension into the water column.

The life strategies of benthic dinoflagellates are poorly known in comparison to planktonic species. The life cycle of $L$. arabicus observed in culture, included a motile biflagellate cell, a nonmotile short-term thin-walled division cyst, and a thick-walled resting stage. Culture observation of $L$. arabicus revealed asexual reproduction of the eleutheroschisis type within temporary cyst as is typical in peridinialeans (e.g., Pfiester and Anderson 1987, Fensome et al. 1993, Bravo and Figueroa 2014). In aging cultures, Laciniporus arabicus produced abundant organic-walled spiny resting cysts in response to nutrient depletion. Gross morphology of the resting cyst is similar to those described in life cycles of some other dinoflagellates. For instance, spherical thick-walled resting cysts with a red accumulation body covered with organic spines of different shape have been described for

This article is protected by copyright. All rights reserved. 
Pentapharsodinium dalei (Gu et al. 2013), Protoceratium reticulatum (Salgado et al. 2017), Lingulodinium polyedra (Figueroa and Bravo 2005) and are considered as a hypnozygote stage.

Further studies are needed to clarify whether the thick-walled resting cyst of $L$. arabicus originates from sexual reproduction, since no morphologically recognizable gametes or planozygotes were found in this study. Nevertheless, these resting cysts might be associated with resistance of $L$. arabicus to unfavorable conditions.

To date, the known distribution of $L$. arabicus is restricted to subtropical and tropical areas of the northern Indian Ocean. The species was found from distant localities around the Arabian Peninsula in Kuwait (northwestern Persian Gulf), southern Oman (Arabian Sea), and Jordan (northern Red Sea) from submerged sandy sediments in subtidal areas at rather a narrow range of water temperatures $\left(23-27^{\circ} \mathrm{C}\right)$ and salinities (35-41). The Jordanian and Kuwaiti specimens were morphologically very close to the strain of L. arabicus from the type locality but their actual identity needs to be confirmed from molecular evidence.

The SSU rDNA based molecular phylogeny was unable to resolve the relationship of $L$. arabicus with any other dinoflagellate and its position was never supported. However, the tree inferred from LSU rDNA placed the newly described marine, sand-dwelling, photosynthetic, noncalcareous $L$. arabicus in the same cluster that the marine planktonic calcareous-cyst producing scrippsielloid dinoflagellates, parasitic Duboscquodinium collinii, and the mostly freshwater heterotrophic predatory pfiesteriaceans, coccoid Thoracosphaera heimii and photosynthetic Chimonodinium lomnickii and Apocalathium spp. These relations received high support from both posterior probability and bootstrap analysis (Fig. 9), although the position of L. arabicus can not be resolved with more detail (polytomy).

The structure of finely thecate dinospore stage of the parasitic Duboscquodinium collinii and the swimming stage of the coccoid Thoracosphaera heimii is not known in enough detail for comparison with L. arabicus (Tangen et al. 1982, Coats et al. 2010). Laciniporus arabicus differs 
morphologically from its most closely related taxa with known thecal tabulation, in epithecal plate arrangement possessing two anterior intercalary plates rather than one (as in Pfiesteria) or three (as in Scrippsiella, Chimonodinium, and Apocalathium), and seven precingular plates rather than six as in Luciella or five as in Pfiesteria (Table 1). However, the number of cingular plates and the basic arrangement of sulcal plates are shared characteristics with close relatives, suggesting the importance of the furrows' structure in the taxonomy of the peridinioid dinoflagellates (Balech, 1980). Along with morphological distinction, L. arabicus differs from the scrippsielloid taxa in lacking a calcareous coccoid stage in its life cycle, and it is clearly separated in physiological sense from the heterotrophic predatory pfiesteriacean dinoflagellates that use a peduncle to ingest parts of their prey and have a complex life cycle. In addition, the compared species occupy different habitats (Table 1), whereas only distant relations were found to other benthic dinoflagellates, including species of the genus Durinskia (Fig. 9).

In conclusion, the characteristic morphology coupled with phylogenetic analyses using partial LSU rDNA sequences support the placement of Laciniporus arabicus within the order Peridiniales, family Thoracosphaeraceae. However, its discrepancy from other members of Thoracosphaeraceae is sufficient to warrant a separate genus.

\section{ACKNOWLEDGMENTS}

We highly appreciate Igor Polikarpov (Kuwait Institute for Scientific Research, Kuwait) valuable help with sampling and kind support during this work. We also thank Mikhail Chesalin (Fisheries Research Center, Salalah, Oman) for help in field sampling and hospitality in Salalah. The authors wish to thank Gwenaël Bilien (IFREMER, LER BO, Station de Biologie Marine, Concarneau, France) for her assistance with the molecular work, and Andrey Sazhin (P.P. Shirshov Institute of Oceanology, Moscow, Russia) for providing the optical facilities. We acknowledge the help of Ahlam S. Al-Kadi

This article is protected by copyright. All rights reserved. 
and Mohammed T. Rajab (Nanoscopy Science Center, Kuwait University, Kuwait) and Viktor Karlov (P.P. Shirshov Institute of Oceanology, Moscow, Russia) for their skilful technical assistance with SEM. Thanks to Jacob Larsen (IOC Science and Communication Centre on Harmful Algae, University of Copenhagen, Denmark) for his comments on an earlier version of the manuscript. We are grateful to anonymous reviewers for their detailed and constructive comments. This study was supported in part by the Foreign Fellow Scientist Program at the French Research Institute for Exploitation of the Sea (IFREMER, LER BO, Station de Biologie Marine, Concarneau, France). The authors declare no conflict of interest.

\section{REFERENCES}

Abé, T. 1981. Studies on the family Peridiniales. Seto Mar. Biol. Lab. Special Publ. Ser. 6:1-409.

Al-Yamani, F. \& Saburova, M. 2010. Illustrated Guide on the Flagellates of Kuwait's Intertidal Soft Sediments. Kuwait Institute for Scientific Research, Kuwait, 197 pp.

Annenkova, N., Hansen, G., Moestrup, $\varnothing$. \& Rengefors, K. 2015. Recent adaptive radiation in a marine and freshwater dinoflagellate species flock. ISME J. 9:1821-34.

Azovsky, A., Saburova, M., Tikhonenkov, D., Khazanova, K., Esaulov, A. \& Mazei, Y. 2013. Composition, diversity and distribution of microbenthos across the intertidal zones of Ryazhkov Island (the White Sea). Eur. J. Protistol. 49:500-15.

This article is protected by copyright. All rights reserved. 
Balech, E. 1959. Two new genera of dinoflagellates from California. Biol. Bull. 116:195-203.

Balech, E. 1974. El género Protoperidinium Bergh, 1881 (Peridinium Ehrenberg, 1831, partim). Rev. Mus. Arg. Cs. Nat. 'B. Rivadavia' Hydrobiologia 4:1-79.

Balech, E. 1980. On the thecal morphology of dinoflagellates with special emphasis on circular and sulcal plates. An. Centro Cienc. del Mar y Limnol. Univ. Nal. Autón. México 7:57-68.

Boltovskoy, A. 1999. Contribución al conocimiento de los dinoflagelados de la República Argentina. Tesis No 716 de la Facultad de Ciencias Naturales y Museo de La Plata, Univ. Nac. La Plata, 115 pp.

Bravo, I. \& Figueroa, R. I. 2014. Towards an ecological understanding of dinoflagellate cyst functions. Microorganisms 2:11-32.

Calado, A. J. \& Craveiro, S. C. 2009. Description of Tyrannodinium gen. nov., a freshwater dinoflagellate closely related to the marine Pfiesteria-like species. J. Phycol. 45:1195-1205.

Carty, S. 2008. Parvodinium gen. nov. for the umbonatum group of Peridinium (Dinophyceae). Ohio J. Sci. 108:103-7.

This article is protected by copyright. All rights reserved. 
Catania, D., Richlen, M. L., Mak, Y. L., Morton, S. L., Laban, E. H., Xu, Y., Anderson, D. M., Chan, L. L. \& Berumen M. L. 2017. The prevalence of benthic dinoflagellates associated with ciguatera fish poisoning in the central Red Sea. Harmful Algae 68:206-16.

Chiffings, A. W. 1995. Marine Region 11: Arabian Seas. In Kelleher, G., Bleakley, C. \& Wells, S. [Eds.] A Global Representative System of Marine Protected Areas. Vol III. Central Indian Ocean, Arabian Seas, East Africa and East Asian Seas. The Great Barrier Reef Marine Park Authority, World Bank and IUCN, Washington, D.C., pp. 39-71.

Chomérat, N. \& Bilien, G. 2014. Madanidinium loirii gen. et sp. nov. (Dinophyceae), a new marine benthic dinoflagellate from Martinique Island, Eastern Caribbean. Eur. J. Phycol. 49:165-78.

Chomérat, N. \& Couté, A. 2008. Protoperidinium bolmonense sp. nov. (Peridiniales, Dinophyceae), a small dinoflagellate from a brackish hypereutrophic lagoon (South of France). Phycologia 47:392403.

Chomérat, N. \& Nézan, E. 2009. Cabra reticulata sp. nov. (Dinophyceae), a new sand-dwelling dinoflagellate from the Atlantic Ocean. Eur. J. Phycol. 44:415-23.

Chomérat, N., Couté, A. \& Nézan, E. 2010. Further investigations on the sand-dwelling genus Cabra (Dinophyceae, Peridiniales) in South Brittany (northwestern France), including the description of $C$. aremorica sp. nov. Mar. Biodiv. 40:131-42.

This article is protected by copyright. All rights reserved. 
Chomérat, N., Saburova, M., Bilien, G. \& Al-Yamani, F. 2012. Prorocentrum bimaculatum sp. nov.

(Dinophyceae, Prorocentrales), a new benthic dinoflagellate species from Kuwait (Arabian Gulf). J.

Phycol. 48:211-21.

Coats, D. W., Kim, S., Bachvaroff, T. R., Handy, S. M. \& Delwiche, C. F. 2010. Tintinnophagus acutus n.g., n. sp. (Phylum Dinoflagellata), an ectoparasite of the ciliate Tintinnopsis cylindrica

Daday 1887, and its relationship to Duboscquodinium collini Grassé 1952. J. Eukaryot. Microbiol. $57: 468-82$.

Craveiro, S. C., Moestrup, Ø., Daugbjerg, N. \& Calado, A. J. 2010. Ultrastructure and large subunit rDNA-based phylogeny of Sphaerodinium cracoviense, an unusual freshwater dinoflagellate with a novel type of eyespot. J. Eukaryot. Microbiol. 57:568-85.

Craveiro, S. C., Calado, A. J., Daugbjerg, N., Hansen, G. \& Moestrup, $\varnothing$. 2011. Ultrastructure and LSU rDNA-based phylogeny of Peridinium lomnickii and description of Chimonodinium gen. nov. (Dinophyceae). Protist 162:590-615.

Craveiro, S. C., Pandeirada, M. S., Daugbjerg, N., Moestrup, $\varnothing$. \& Calado, A. J. 2013. Ultrastructure and phylogeny of Theleodinium calcisporum gen. et sp. nov., a freshwater dinoflagellate that produces calcareous cysts. Phycologia 52:488-507.

This article is protected by copyright. All rights reserved. 
Craveiro, S. C., Daugbjerg, N., Moestrup, $\varnothing$. \& Calado, A. J. 2015. Fine-structural characterization and phylogeny of Peridinium polonicum, type species of the recently described genus Naiadinium (Dinophyceae). Eur. J. Protistol. 51:259-79.

Craveiro, S. C., Daugbjerg, N., Moestrup, $\varnothing \&$ Calado, A. J. 2016. Studies on Peridinium aciculiferum and Peridinium malmogiense (=Scrippsiella hangoei): comparison with Chimonodinium lomnickii and description of Apocalathium gen. nov. (Dinophyceae). Phycologia 56: 21-35.

Dodge, J. D. \& Hermes, H. 1981. A revision of the Diplopsalis group of dinoflagellates based on material from the British Isles. Bot. J. Linn. Soc. 83:15-26.

Faust, M. A. \& Balech, E. 1993. A further SEM study of marine benthic dinoflagellates from a mangrove island, Twin Cays, Belize, including Plagiodinium belizeanum gen. et sp. nov. J. Phycol. 29:826-32.

Fensome, R. A., Taylor, F. J. R., Norris, D. R., Sargeant, W. A. S., Wharton, D. I. \& Williams, G. L. 1993. A Classification of Living and Fossil Dinoflagellates. Micropaleontology Spec. Publ. 7, 351 pp.

Figueroa, R. I. \& Bravo, I. 2005. Sexual reproduction and two different encystment strategies of Lingulodinium polyedrum (Dinophyceae) in culture. J. Phycol. 41:370-9.

This article is protected by copyright. All rights reserved. 
Fraga, S., Rodríguez, F., Bravo, I., Zapata, M. \& Marañón, E. 2012. Review of the main ecological features affecting benthic dinoflagellate blooms. Cryptogam. Algol. 33:171-9.

Fritz, L. \& Triemer, R. E. 1985. A rapid simple technique utilizing calcofluor white MR2 for the visualization of dinoflagellate thecal plates. J. Phycol. 21:662-4.

Gómez, F. 2012. A quantitative review of the lifestyle, habitat and trophic diversity of dinoflagellates (Dinoflagellata, Aveolata). Syst. Biodivers. 10: 267-75.

Gu, H., Luo, Z., Zeng, N., Lan, B. \& Lan D. 2013. First record of Pentapharsodinium (Peridiniales, Dinophyceae) in the China Sea, with description of Pentapharsodinium dalei var. aciculiferum. Phycol. Res. 61:256-67.

Guindon, S., Dufayard, J. F., Lefort, V., Anisimova, M., Hordijk, W. \& Gascuel, O. 2010. New algorithms and methods to estimate Maximum-Likelihood phylogenies: assessing the performance of PhyML 3.0. Syst. Biol. 59:307-21.

Hameed, H. A. \& Saburova, M. 2015. First record of Scrippsiella trochoidea (Dinophyceae) in Shatt AlArab River (Southern Iraq). Mar. Biodivers. Rec. 8:e150.

Hansen, G. \& Flaim, G. 2007. Dinoflagellates of the Trentino Province, Italy. J. Limnol. 66:107-41.

This article is protected by copyright. All rights reserved. 
Hoppenrath, M. 2000a. Morphology and taxonomy of six marine sand-dwelling Amphidiniopsis species (Dinophyceae, Peridiniales), four of them new, from the German Bight, North Sea.

Phycologia 39: 482-97.

Hoppenrath, M. 2000b. Taxonomische und ökologische Untersuchungen von Flagellaten mariner Sande. Ph.D. Dissertation, Biologische Fakultät, Universität Hamburg, Germany, 311 pp.

Hoppenrath, M. \& Selina, M. 2006. Pseudothecadinium campbellii gen. nov. sp. nov. (Dinophyceae), a phototrophic, thecate, marine planktonic species found in the Sea of Okhotsk, Russia. Phycologia 45:260-9.

Hoppenrath, M. \& Elbrächter, M. 2017. CEDIT: Centre of Excellence for Dinoflagellate Taxonomy. Available at: http://www.dinophyta.org (last accessed 26 March 2017).

Hoppenrath, M., Schweikert, M. \& Elbrächter M. 2003. Morphological reinvestigation and characterization of the marine, sand-dwelling dinoflagellate Adenoides eludens (Dinophyceae). Eur. J. Phycol. 38:385-94.

Hoppenrath, M., Horiguchi, T., Miyoshi, Y., Selina, M., Taylor, F. J. R. \& Leander, B. S. 2007. Taxonomy, phylogeny, biogeography, and ecology of Sabulodinium undulatum (Dinophyceae), including an emended description of the species. Phycol. Res. 55:159-75.

This article is protected by copyright. All rights reserved. 
Hoppenrath, M., Koeman, R. P. T. \& Leander, B. S. 2009. Morphology and taxonomy of a new marine sand-dwelling Amphidiniopsis species (Dinophyceae, Peridiniales), A. aculeata, from Cap Feret, France. Mar. Biodivers. 39:1-7.

Hoppenrath, M., Chomérat, N., Horiguchi, T., Schweikert, M., Nagahama, Y. \& Murray, S. 2013. Taxonomy and phylogeny of the benthic Prorocentrum species (Dinophyceae) - a proposal and review. Harmful Algae 27:1-28.

Hoppenrath, M., Murray, S., Chomérat, N. \& Horiguchi, T. 2014. Marine Benthic Dinoflagellates Unveiling Their Worldwide Biodiversity. Kleine Senckenberg-Reihe 54. Stuttgart: Schweizerbart'sche Verlagsbuchhandlung, $276 \mathrm{pp}$.

Horiguchi, T. 1995. Amphidiniella sedentaria gen. et sp. nov. (Dinophyceae), a new sand-dwelling dinoflagellate from Japan. Phycol. Res. 43:93-9.

Horiguchi, T. \& Chihara, M. 1983a. Stylodinium littorale, a new marine dinococcalean alga (Pyrrhophyta). Phycologia 22:23-8.

Horiguchi, T. \& Chihara, M. 1983b. Scrippsiella hexapraecingula sp. nov. (Dinophyceae), a tide pool dinoflagellate from the Northwest Pacific. Bot. Mag. Tokyo 96:351-8.

This article is protected by copyright. All rights reserved. 
Horiguchi, T. \& Kubo, F. 1997. Roscoffia minor sp. nov. (Peridiniales, Dinophyceae); a new, sanddwelling, armored dinoflagellate from Hokkaido, Japan. Phycol. Res. 45:65-9.

Horiguchi, T. \& Pienaar, R. N. 1988. Ultrastructure of a new sand-dwelling dinoflagellate, Scrippsiella arenicola sp. nov. J. Phycol. 24:426-38.

Janofske, D. 2000. Scrippsiella trochoidea and Scrippsiella regalis, nov. comb. (Peridiniales, Dinophyceae): a comparison. J. Phycol. 36:178-89.

Jeong, H. J., Yih, W., Kang, N. S., Lee, S. Y., Yoon, E. Y., Yoo, Y. D., Kim, H. S. \& Kim, J. H. 2012. First report of the epiphytic benthic dinoflagellates Coolia canariensis and Coolia malayensis in the waters off Jeju Island, Korea: morphology and rDNA sequences. J. Eukaryot. Microbiol. 59:114-33.

Jeong, H. J., Kang, N. S., Moestrup, Ø., Yoo, Y. D. \& Potvin, E. 2014. Description of the new heterotrophic dinoflagellate Stoeckeria changwonensis n. sp from Korean coastal waters and emended description of the genus Stoeckeria and the type species Stoeckeria algicida. Harmful Algae 36:38-56.

Kang, N. S., Jeong, H. J., Lee, S. Y., Lim, A. S., Lee, M. J., Kim, H. S. \& Yih, W. H. 2013. Morphology and molecular characterization of the epiphytic benthic dinoflagellate Ostreopsis cf. ovata in the temperate waters off Jeju Island, Korea. Harmful Algae 27:98-112.

This article is protected by copyright. All rights reserved. 
Kang, N. S., Jeong, H. J., Moestrup, Ø., Jang, T. Y., Lee, S. Y. \& Lee, M. J. 2015. Aduncodinium gen. nov. and A. glandula comb. nov. (Dinophyceae, Pfiesteriaceae), from coastal waters off Korea: Morphology and molecular characterization. Harmful Algae 41:25-37.

Katoh, K. \& Standley, D. M. 2013. MAFFT multiple sequence alignment software version 7: improvements in performance and usability. Mol. Biol. Evol. 30:772-80.

Keller, M. D. \& Guillard, R. R. L. 1985. Factors significant to marine diatom culture. In Anderson, D.M., White, A.W. \& Baden, D.G. [Eds.] Toxic Dinoflagellates. Elsevier, New York, pp. 113-6.

Keller, M. D., Selvin, R. C., Claus, W. \& Guillard, R. R. L. 1987. Media for the culture of oceanic ultraphytoplankton. J. Phycol. 23:633-8.

Kempton, J. W., Wolny, J., Tengs, T., Rizzo, P., Morris, R., Tunnell, J., Scott, P., Steidinger, K., Hymel, S. N. \& Lewitus, A. J. 2002. Kryptoperidinium foliaceum blooms in South Carolina: A multianalytical approach to identification. Harmful Algae 1:383-92.

Kofoid, C. A. 1909. On Peridinium steinii Jörgensen, with a note on the nomenclature of the skeleton of the Peridinidae. Arch. Protistenk. 16:25-47.

This article is protected by copyright. All rights reserved. 
Kofoid, C. A. 1911. Dinoflagellata of the San Diego region, IV. The genus Gonyaulax, with notes on its skeletal morphology and a discussion of its generic and specific characters. Univ. Calif. Publ. Zool. 8:187-286.

Larsen, J., Kuosa, H., Ikävalko, J., Kivi, K. \& Hällfors, S. 1995. A redescription of Scrippsiella hangoei (Schiller) comb. nov. - a 'red tide' dinoflagellate from the northern Baltic. Phycologia 34:135-44.

Leaw, C. P., Lim, P. T., Cheng, K. W., Ng, B. K. \& Usup, G. 2010. Morphology and molecular characterization of a new species of thecate benthic dinoflagellate, Coolia malayensis sp. nov. (Dinophyceae). J. Phycol. 46:162-71.

Lewis, J. 1991. Cyst-theca relationships in Scrippsiella (Dinophyceae) and related orthoperidinioid genera. Bot. Mar. 34:91-106.

Litaker, R. W., Steidinger, K. A., Mason, P. L., Landsberg, J. H., Shields, J. D., Reece, K. S., Haas, L. W., Vogelbein, W. K., Vandersea, M. W., Kibler, S. R. \& Tester, P. A. 2005. The reclassification of Pfiesteria shumwayae (Dinophyceae): Pseudopfiesteria, gen. nov. J. Phycol. 41:643-51.

Liu, T., Mertens, K. N. \& Gu, H. 2015. Cyst-theca relationship and phylogenetic position of the diplopsalioideans (Peridiniales, Dinophyceae), with description of Niea and Qia gen. nov. Phycologia 54: $210-32$.

This article is protected by copyright. All rights reserved. 
Mason, P. L., Litaker, R. W., Jeong, H. J., Ha, J. H., Reece, K. S., Stokes, N. A., Park, J. Y., Steidinger, K. A., Vandersea, M. W., Kibler, S., Tester, P. A. \& Vogelbein, W. K. 2007. Description of a new genus of Pfiesteria-like dinoflagellate, Luciella gen. nov. (Dinophyceae), including two new species: Luciella masanensis sp. nov. and Luciella atlantis sp. nov. J. Phycol. 43:799-810.

Munir, S., Siddiqui, P. J. A. \& Morton, S. L. 2011. The occurrence of ciguatera fish poisoning producing dinoflagellate genus Gambierdiscus in Pakistan waters. Algae 26:314-25.

Murray, S., 2003. Diversity and phylogenetics of sand-dwelling dinoflagellates from Southern Australia. Ph.D. Dissertation. University of Sydney, Australia, 202 pp.

Murray, S. \& Patterson, D. J. 2002. Amphidiniopsis korewalensis sp. nov., a new heterotrophic benthic dinoflagellate. Phycologia 41:382-8.

Murray, S. \& Patterson, D. J. 2004. Cabra matta, gen. nov., sp. nov., a new benthic, heterotrophic dinoflagellate. Eur. J. Phycol. 39:229-34.

Murray, S., Hoppenrath, M., Preisfeld, A., Larsen, J., Yoshimatsu, S., Toriumi, S. \& Patterson, D. J. 2006. Phylogenetics of Rhinodinium broomeense gen. et sp. nov., a peridinioid, sand-dwelling dinoflagellate (Dinophyceae). J. Phycol. 42:934-42.

This article is protected by copyright. All rights reserved. 
Nézan, E. \& Chomérat, N. 2011. Vulcanodinium rugosum gen. et sp. nov. (Dinophyceae), un nouveau dinoflagellé marin de la côte méditerranéenne française. Cryptog. Algol. 32:3-18.

Nézan, E., Tillmann, U., Bilien, G. L., Boulben, S., Chèze, K., Zentz, F., Salas, R. \& Chomérat, N. 2012. Taxonomic revision of the dinoflagellate Amphidoma caudata: Transfer to the genus Azadinium (Dinophyceae) and proposal of two varieties, based on morphological and molecular phylogenetic analyses. J. Phycol. 48:925-39.

Pfiester, L. A. \& Anderson, D. M. 1987. Dinoflagellate Reproduction. In Taylor, F. J. R. [Ed.] The Biology of Dinoflagellates. Blackwell Scientific; Oxford, UK, pp. 611-48.

Posada, D. 2008. jModelTest: Phylogenetic model averaging. Mol. Biol. Evol. 25:1253-56.

Rengefors, K. \& Meyer, B. 1998. Peridinium euryceps sp. nov. (Peridiniales, Dinophyceae), a cryophilic dinoflagellate from Lake Erken, Sweden. Phycologia 37:284-91.

Rixen, T., Haake, B. \& Ittekkot, V. 2000. Sedimentation in the western Arabian Sea: the role of coastal and open-ocean upwelling. Deep Sea Res. // 47:2155-78.

Ronquist, F. \& Huelsenbeck, J. P. 2003. MrBayes 3: Bayesian phylogenetic inference under mixed models. Bioinformatics 19:1572-4.

This article is protected by copyright. All rights reserved. 
Saburova, M. \& Chomérat, N. 2014. Ailadinium reticulatum gen. et sp. nov. (Dinophyceae), a new thecate, marine, sand-dwelling dinoflagellate from the northern Red Sea. J. Phycol. 50:1120-36.

Saburova, M. \& Chomérat, N. 2016. An emended description and phylogeny of the little-known Prorocentrum sipadanense Mohammad-Noor, Daugbjerg \& Moestrup (Prorocentrales, Dinophyceae) from the Indian Ocean, Oman. Eur. J. Phycol. 51:270-81.

Saburova, M., Al-Yamani, F. \& Polikarpov, I. 2009. Biodiversity of free-living flagellates in Kuwait's intertidal sediments. In Krupp, F., Musselman, L. J., Kotb, M. M. A. \& Weidig, I. [Eds.] Environment, Biodiversity and Conservation in the Middle East. Proceedings of the First Middle Eastern Biodiversity Congress. Aqaba, Jordan, 20-23 October 2008. Biorisk 3:97-110.

Saburova, M., Chomérat, N. \& Hoppenrath, M. 2012a. Morphology and SSU rDNA phylogeny of Durinskia agilis (Kofoid \& Swezy) comb. nov. (Peridiniales, Dinophyceae), a thecate, marine, sanddwelling dinoflagellate formerly classified within Gymnodinium. Phycologia 51:287-302.

Saburova, M., Polikarpov, I. \& AI-Yamani, F. 2012b. First record of Kryptoperidinium foliaceum (Dinophyceae: Peridiniales) from a hypersaline environment in Kuwait, northwestern Arabian Gulf. Mar. Biodiversity Rec. 5:e104.

Saburova, M., Polikarpov, I. \& Al-Yamani, F. 2013. New records of the genus Gambierdiscus in marginal seas of the Indian Ocean. Mar. Biodiversity Rec. 6:e91.

This article is protected by copyright. All rights reserved. 
Salgado, P., Figueroa, R. I., Ramilo, I. \& Bravo, I. 2017. The life history of the toxic marine dinoflagellate Protoceratium reticulatum (Gonyaulacales) in culture. Harmful Algae 68:67-81.

Saunders, R. D. \& Dodge, J. D. 1984. An SEM study and taxonomic revision of some armoured sanddwelling marine dinoflagellates. Protistologica 20:271-83.

Selina, M. \& Hoppenrath, M. 2013. Morphology and taxonomy of seven marine sand-dwelling Amphidiniopsis species (Peridinales, Dinophyceae), including two new species, A. konovalovae sp. nov. and A. striata sp. nov., from the Sea of Japan, Russia. Mar. Biodivers. 43:87-104.

Selina, M. S. \& Morozova, T. V. 2017. Morphology and taxonomy of three new marine sand-dwelling Amphidiniopsis species (Peridiniales, Dinophyceae) from the Sea of Japan, Russia. Phycologia 56:113.

Sievers, F., Wilm, A., Dineen, D.G., Gibson, T.J., Karplus, K., Li, W., Lopez, R., McWilliam, H., Remmert, M., Söding, J., Thompson, J.D. \& Higgins, D.G. 2011. Fast, scalable generation of high-quality protein multiple sequence alignments using Clustal Omega. Mol. Syst. Biol. 7:539.

Steidinger, K. A. \& Tangen, K. 1997. Dinoflagellates. In Tomas, C. R. [Ed.] Identifying Marine Phytoplankton. Academic Press, San Diego, pp. 387-584.

This article is protected by copyright. All rights reserved. 
Steidinger, K. A., Burkholder, J. M., Glasgow, H. B. Jr., Hobbs, C. W., Garrett, J. K., Truby, E. W., Noga, E. J. \& Smith, S. A. 1996. Pfiesteria piscicida gen. et sp. nov. (Pfiesteriaceae fam. nov.), a new toxic dinoflagellate with a complex life cycle and behavior. J. Phycol. 32:157-64.

Talavera, G. \& Castresana, J. 2007. Improvement of phylogenies after removing divergent and ambiguously aligned blocks from protein sequence alignments. Syst. Biol. 56:564-77.

Tamura, M. \& Horiguchi, T. 2005. Pileidinium ciceropse gen. et sp. nov. (Dinophyceae), a sanddwelling dinoflagellate from Palau. Eur. J. Phycol. 40:281-91.

Tangen, K., Brand, L. E., Blackwelder, P. L. \& Guillard, R. R. L. 1982. Thoracosphaera heimii (Lohmann) Kamptner is a dinophyte: observations on its morphology and life cycle. Mar. Micropaleontol. 7:193212.

Taylor, F. J. R., Hoppenrath, M. \& Saldarriaga, J. F. 2008. Dinoflagellate diversity and distribution. Biodivers. Conserv. 17:407-18.

Toriumi, S., Yoshimatsu, S. \& Dodge, J. D. 2002. Amphidiniopsis uroensis sp. nov. and Amphidiniopsis pectinaria sp. nov. (Dinophyceae): two new benthic dinoflagellates from Japan. Phycol. Res. 50:11524.

This article is protected by copyright. All rights reserved. 
Uhlig, G. 1964. Eine einfache Methode zur Extraktion der vagilen mesopsammalen Mikrofauna. Helgol. Wiss. Meeresunters. 11:178-85.

Yamaguchi, A., Hoppenrath, M., Pospelova, V., Horiguchi, T. \& Leander, B. S. 2011. Molecular phylogeny of the marine sand-dwelling dinoflagellate Herdmania litoralis and an emended description of the closely related planktonic genus Archaeperidinium Jörgensen. Eur. J. Phycol. 46:98-112.

This article is protected by copyright. All rights reserved. 
Table 1. Comparison of morphological characteristics of Laciniporus arabicus with related dinoflagellate taxa

\begin{tabular}{|c|c|c|c|c|c|c|c|c|c|c|c|}
\hline Taxon & APC & ' & a & " & c & $\mathbf{s}$ & '"' & 'I'!' & $\begin{array}{l}\text { Apical } \\
\text { hook }\end{array}$ & $\begin{array}{l}\text { Chloro- } \\
\text { plasts }\end{array}$ & Habitat \\
\hline Laciniporus arabicus $^{\mathrm{a}}$ & Po, $X$ & 4 & 2 & 7 & 6 & 6 [Sa Sd afp pfp Ss Sp] & 5 & 2 & + & + & marine \\
\hline Stroeckeria spp. ${ }^{b}$ & Po, $c p, X$ & 4 & 2 & 7 & 6 & $\mathrm{PC}+5$ [Sa Sdp Sm Ss Sp] & 5 & 2 & - & - & marine \\
\hline Naiadinium polonicum $^{c}$ & Po, $c p, X$ & 4 & $1-2$ & 7 & 6 & 5 [Sa Sd Sp +2] & 5 & 2 & + & + & freshwater \\
\hline Parvodinium spp. ${ }^{d}$ & Po, $X$ & 4 & 2 & 7 & 6 & 5 [Sa Sd Sm Ss Sp] & 5 & 2 & - & + & freshwater \\
\hline Theleodinium calciporum ${ }^{\mathrm{e}}$ & Po, $c p, X$ & $3(4)$ & 2 & 7 & 6 & $5(6 ?)$ [Sa Sd Ss Sp +2?] & 5 & 2 & - & + & freshwater \\
\hline Durinskia agilis $^{\dagger}$ & Po, $x$ & 4 & 2 & 7 & 5 & 6 [Sa Sd Sma Smp Ss Sp] & 5 & 2 & + & + & marine \\
\hline Durinskia cf. baltica ${ }^{\mathrm{g}, \mathrm{h}}$ & Po, $X$ & 4 & 2 & 7 & 5 & 4(5?) [Sa Sd Sm? Ss Sp] & 5 & 2 & - & + & marine \\
\hline Scrippsiella spp..$^{i-k}$ & Po, $X$ & 4 & 3 & 7 & 6 & $4-6$ & 5 & 2 & - & + & marine \\
\hline Scrippsiella trochoidea $a^{\mathrm{k}, 1}$ & Po, $X$ & 4 & 3 & 7 & 6 & $6[$ Sa Sd af pf Ss Sp] & 5 & 2 & - & + & marine \\
\hline Protoperidinium spp. ${ }^{\mathrm{m}}$ & Po, $X$ & 4 & $2-3$ & 7 & 4 & $6(7)$ & 5 & 2 & - & - & marine \\
\hline
\end{tabular}

This article is protected by copyright. All rights reserved. 
Archaeperidinium spp. ${ }^{\mathrm{n}}$

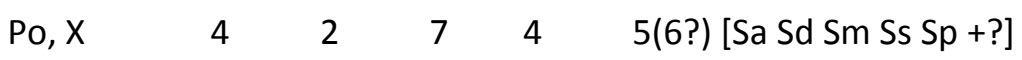

52

marine

Amphidiniopsis aculeata

Po

$\begin{array}{lllll}4 & 2 & 7 & 3 & 5\end{array}$ [Sa Sd Sm Ss Sp]

52

marine

Amphidiniopsis konovalovae ${ }^{\mathrm{p}}$

Po, $c p, X$

4

2

4

5 [Sa Sd Sm Ss Sp]

Kryptoperidinium foliaceum ${ }^{q, r}$

Po, $X$

$\begin{array}{lllll}4 & 2 & 7 & 4-5 & 4-5(7) \text { [Sa Sd Ss Sp +] }\end{array}$

Herdmania litoralis $^{\mathrm{n}}$

Po

$3-4 \quad 2-3$

6-7 5(7) 3-5(6?) [Sa ' $x^{\prime}$ Sd 6"' Sm Ss Sp]

52

52

52

52

52

52

52

Apocalathium euryceps ${ }^{\mathrm{v}}$

Po, $X$

4

7

6

5 [Sa Sd Sm Ss Sp]

Apocalathium malmogiense (syn.

Po, $X$

$3(4)$

6

7 [Sa Sd Ss Sp +3]

Scrippsiella hangoei $)^{\mathrm{u}, \mathrm{w}}$

Luciella spp. ${ }^{\times}$

$\begin{array}{llllll}\text { Po, } \mathrm{cp}, \mathrm{X} & 4 & 2 & 6 & 6 & \mathrm{PC}+5+\text { [Sa Sdp Sm Ss Sp +?] } \\ \text { Po, } \mathrm{cp}, \mathrm{X} & 4 & 1 & 5 & 6 & \mathrm{PC}+5+\text { [Sa Sdp Sm Ss Sp +?] }\end{array}$

Pfiesteria piscicida ${ }^{\mathrm{y}, \mathrm{z}}$

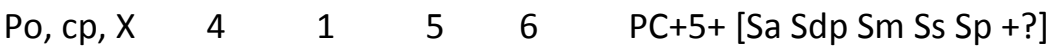

5

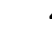

5

52

\section{marine}

marine

marine

freshwater

marine

freshwater

freshwater

brackish

water

marine

marine

This article is protected by copyright. All rights reserved. 


0

$6 \quad 6$

$\mathrm{PC}+5+[\mathrm{Sa}$ Sd Sm Ss Sp +?]

Amphidiniella sedentaria ${ }^{\mathrm{ab}}$

Po

$\begin{array}{lllll}4 & 1 & 7 & 5 & 4 \text { [Sa Sd Ss Sp] }\end{array}$

$5 \quad 2$

freshwater

The epithecal and hypothecal plate designations follow that of Balech (1980): ' (apical plate series), a (anterior intercalary plates), " (precingular plate series), c (cingular plate series), s (sulcal plate series), "' (postcingular plate series), and '"' (antapical plate series). Additional plates supplement the Kofoidian series, namely, APC (apical pore complex), Po (pore plate), cp (closing plate), $\mathbf{X}$ (canal plate), ' $\mathbf{x}$ ' (' $\mathbf{X}$ ' plate), and PC (peduncle cover plate). For sulcal plates (s) the following designations are used: Sa (anterior sulcal plate), Sd (right sulcal plate), Sda (anterior right sulcal plate), Sdp (posterior right sulcal plate), Sma (anterior mid sulcal plate), Smp (posterior mid sulcal plate), Ss (left sulcal plate), Sp (posterior sulcal plate), afp (anterior flagellar pore plate), and pfp (posterior flagellar pore plate).

a - this study; b - Jeong et al. 2014; c - Craveiro et al. 2015; d - Carty 2008; e - Craveiro et al. 2013; f - Saburova et al. 2012a; g - Murray 2003; h - Azovsky et al. 2013; i - Balech 1959; j - Lewis 1991; k - Janofske 2000; I - Hameed and Saburova 2015; m - Steidinger and Tangen 1997; n - Yamaguchi et al. 2011; o - Hoppenrath et al. 2009; p - Selina and Hoppenrath 2013; q - Kempton et al. 2002; r - Saburova et al. 2012b; s - Craveiro et al. 2011; t - Kang et al. 2015; u - Craveiro et al. 2016; v - Rengefors and Meyer 1998; w - Larsen et al. 1995; x - Mason et al. 2007; y - Steidinger et al. 1996; z - Litaker et al. 2005; aa Calado and Craveiro 2009; ab - Horiguchi 1995.

This article is protected by copyright. All rights reserved. 


\section{FIGURE LEGENDS}

Fig. 1. Map of the studied area showing the location of sampling sites, type locality is marked by asterisk.

Fig. 2. Light micrographs of Laciniporus arabicus gen. et sp. nov. from field samples collected at type locality. (a-g) Bright field (BF) micrographs of live cells: (a) Ventral view, focus in the cell surface. Note the deeply indented cingulum and coloured globule in the cytoplasm (arrowhead). (b) Ventral view, focus in the cell middle plane, showing pusule (p) and apical projection (arrowhead). (c) Ventral view, deep focus, showing coloured globule (white arrowhead), nucleus ( $n$ ) and apical projection (black arrowhead). (d) Small-sized cell in ventral view, deep focus, showing large pyrenoid with a ring-like starch sheaths (arrowhead). (e) Oblique dorsal view, focus in the cell surface, showing large pyrenoid with a ring-like starch sheaths (white arrowhead) and apical projection (black arrowhead). (f) Dorsal view, focus in the cell surface. Note the transverse flagellum running inside the cingulum (arrowhead). (g) Dorsal view focus in the cell middle plane, showing large pyrenoid with ring-like starch sheaths (white arrowhead), apical projection (black arrowhead), and long longitudinal flagellum (Lf, arrows). (h) Cell stained with DAPI and illuminated with UV light, showing nucleus (n). (i, j) Cells illuminated with UV light, showing the chlorophyll autofluorescence and peripheral chloroplast network. (k) Cell stained with Calcofluor White and illuminated with UV light in lateral view, showing the thecal plate pattern and apical projection (arrowhead). Scale bars, $10 \mu \mathrm{m}$.

This article is protected by copyright. All rights reserved. 
Fig. 3. Light micrographs of Laciniporus arabicus gen. et sp. nov. (a-l) Cells stained with Calcofluor White and illuminated with UV light, showing the thecal plate pattern: (a) Ventral view of whole cell. (b) Epitheca in right lateral view. (c) Oblique apical view. (d) Squashed epitheca in apical view. (e) APC and surrounded plates in apical view. (f) Dorsal view of whole cell. (g) Antapical view. (h) Series of cingular plates. ( $i, j)$ Osmotically swollen cells in ventral view, arrowheads point to the anterior and posterior flagellar pore plates. $(k, \mathrm{l})$ Detailed view of the sulcal area in osmotically swollen cells, arrowheads point to the anterior (afp) and posterior ( $\mathrm{pfp}$ ) flagellar pore plates. APC, apical pore complex; Po, apical pore plate; $\mathrm{X}$, canal plate; 1-4', apical plate series; 1a-2a, anterior intercalary plates; $1-7^{\prime \prime}$, precingular plate series; $1-6 c$, cingular plate series; $1-5^{\prime \prime \prime}$, postcingular plate series; 1 $2^{\prime \prime \prime \prime}$, antapical plates; Sa, anterior sulcal plate; Sd, right sulcal plate; Ss, left sulcal plate; Sp, posterior sulcal plate; sl, sulcal list; afp, anterior flagellar plate; pfp, posterior flagellar plate. Scale bars, $10 \mu \mathrm{m}$ in $(a, d, f-j)$ and $5 \mu m$ in $(b, c, e, k, l)$.

Fig. 4. Scanning electron micrographs of Laciniporus arabicus gen. et sp. nov. (a) Ventral view of the holotype specimen. (b) Dorsal view. (c) Apical-left lateral view. (d) Left lateral view. (e) Right lateral view. (f, g) Antapical views of ventral (f) and dorsal (g) cell side. Scale bars, $10 \mu \mathrm{m}$.

Fig. 5. Scanning electron micrographs of Laciniporus arabicus gen. et sp. nov. (a) Apical view of ventral cell side, asterisk marks flap-shaped apical projection. (b, c) Detailed APC and surrounded plates in left lateral (b) and ventral (c) view. Note large (white arrowheads) and small (black arrowheads) thecal pores. (d) Ventral view showing transverse (white arrowheads) and longitudinal (black arrowheads) flagella. (e) Detailed sulcal area in ventral view. (f) Detailed sulcal area in left lateral view, arrowhead points to the flagellar pore. Scale bars, $10 \mu \mathrm{m}$ in (d), $5 \mu \mathrm{m}$ in (a), and $2 \mu \mathrm{m}$ in $(b, c, e, f)$.

This article is protected by copyright. All rights reserved. 
Fig. 6. Micrographs of Laciniporus arabicus gen. et sp. nov. from field samples collected at the geographically distant from the type locality sites. (a-c) Jordan, Gulf of Aqaba, northern Red Sea:

Bright field micrographs of live cells in ventral (a) and dorsal (b) view and scanning electron micrograph of cell in ventral view (c); (d-f) Kuwait, northwestern Persian Gulf: Bright field micrographs of live cells in ventral (d) and dorsal (e) view and scanning electron micrograph of cell in ventral view (f). Note flap-shaped apical projection (black arrowheads), large pyrenoid with ring-like starch sheaths (white arrowhead), and nucleus (n). Scale bars, $10 \mu \mathrm{m}$.

Fig. 7. Light micrographs of life cycle stages observed in culture of Laciniporus arabicus gen. et sp. nov. (strain Om-L-arabic-029). (a) Small motile (left) and large nonmotile (right) cells, showing the difference in size, note the posteriorly located nuclei (n). (b) Nonmotile rounded cell attached to the bottom. (c) DAPI-stained nonmotile rounded cell with theca and centrally located nucleus. (d, e) DAPI-stained (d) and Calcofluor-stained (e) nonmotile cells undergoing ecdysis, white arrowheads point shedding thecae. (f) ecdysal division cyst with smooth pellicular outer layer (black arrowhead), large nucleus ( $\mathrm{n}$ ), and remains of the old theca attached at the bottom (white arrowhead). (g) Division cyst undergoing karyokinesis showing nuclei (n) separation. (h, i) DAPI-stained division cysts showing different stages of karyokinesis and intact chloroplast lobes. (j) Division cyst with two separated nuclei $(n)$ undergoing cytoplasmic cleavage. $(k, l)$ Late stage of cytoplasmic cleavage released from division cyst, empty wall of germinated division cyst is shown in (I) and marked by black arrowheads. (m) Two empty division cysts left after germination. (n) Two recently divided Calcofluor-stained thinly thecate cells near old shedding theca (white arrowhead). (o) Newly formed thick-walled resting cyst with conspicuous orange-red accumulation body. (p) The same cyst stained with Calcofluor showing double-layered wall, orange accumulation body and residual chlorophyll. (q) Mature resting cyst densely covered with spines. ( $r$ ) Empty spiny resting cyst left after germination. Scale bars, $10 \mu \mathrm{m}$.

This article is protected by copyright. All rights reserved. 
Fig. 8. Line drawings of Laciniporus arabicus gen. et sp. nov. showing schematic representation of plate pattern. (a) Ventral view. (b) Dorsal view. (c) Apical view. (d) Antapical view. (e) Detailed sulcal area.

Fig. 9. Maximum likelihood phylogenetic tree inferred from a LSU rDNA matrix ( 52 sequences, 827 characters). Likelihood loglk=--11184.9. The tree was rooted on Triadinium polyedricum (Gonyaulacales). Selected model TN93 $+\mathrm{I}+\mathrm{G}_{4}$ with $\mathrm{I}=0.196$ and (alpha) $=0.643$. Assumed nucleotides frequencies $f(A)=0.24553, f(C)=0.19723, f(G)=0.29058, f(T)=0.26666$. Bootstrap values $>65$ (100 pseudo-replicates in $\mathrm{ML}$ ) and posterior probabilities $>0.90(\mathrm{BI})$ are shown at nodes. ' + ' indicates a branch with a bootstrap below 65 but supported in Bayesian analysis. Thick lines indicate full support (100/1.00).

\section{SUPPLEMENTARY FIGURE LEGEND}

Fig. S1. Maximum likelihood phylogenetic tree inferred from a SSU rDNA matrix (82 sequences, 1743 characters). Likelihood loglk=--22680.7. The tree was rooted on Amoebophrya sp. (Syndiniales). Selected model GTR $+I+G_{4}$ with I $=0.239$ and (alpha) $=0.540$. GTR relative rate parameters. $A \leftrightarrow C=$ 1.48969; $\mathrm{A} \leftrightarrow \mathrm{G}=4.28491 ; \mathrm{A} \leftrightarrow \mathrm{T}=1.41712 ; \mathrm{C} \leftrightarrow \mathrm{G}=0.76982 ; \mathrm{C} \leftrightarrow \mathrm{T}=9.12922$ against $\mathrm{G} \leftrightarrow \mathrm{T}=$ 1.0000. Assumed nucleotides frequencies $f(A)=0.24382, f(C)=0.20680, f(G)=0.26560$, $f(T)=0.28378$. Bootstrap values $>65$ (100 pseudo-replicates in $M L)$ and posterior probabilities $>0.90$ (BI) are shown at nodes. ' + ' indicates a branch with a bootstrap below 65 but supported in Bayesian analysis. Thick lines indicate full support (100/1.00).

This article is protected by copyright. All rights reserved. 


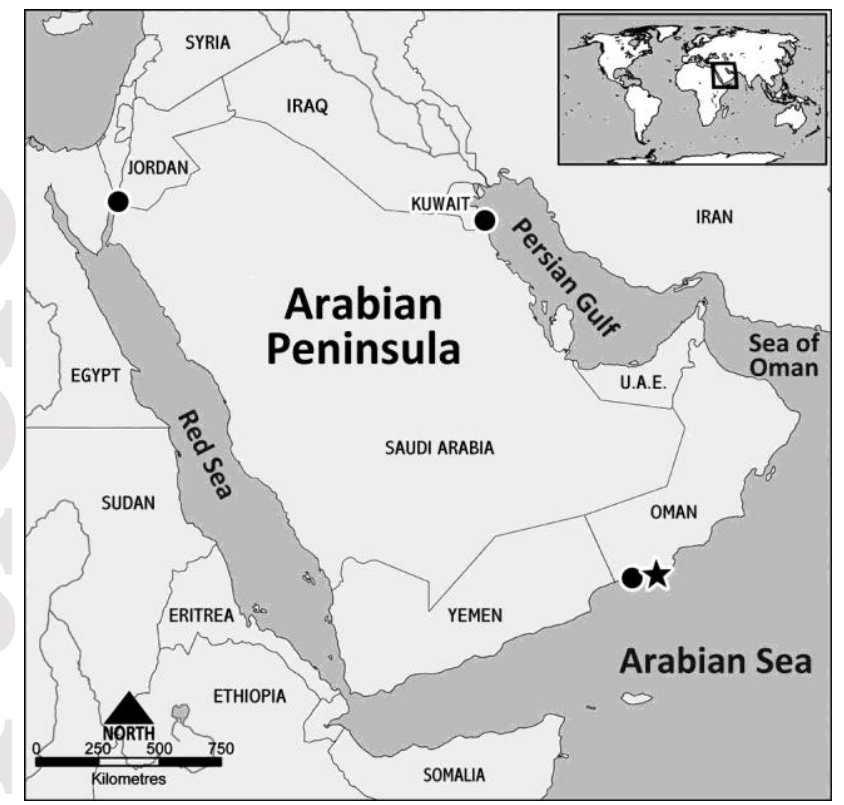

This article is protected by copyright. All rights reserved. 


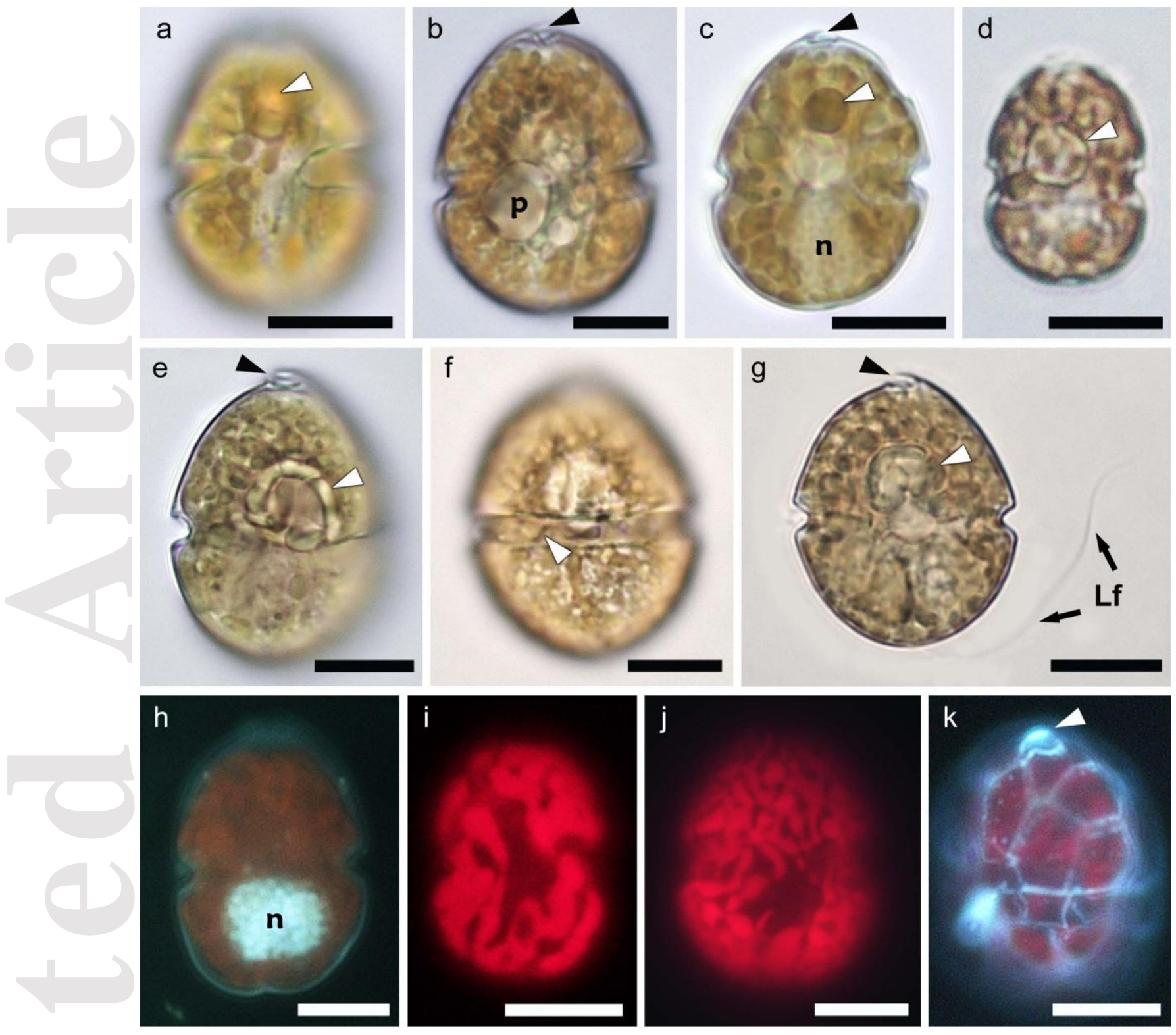

This article is protected by copyright. All rights reserved. 

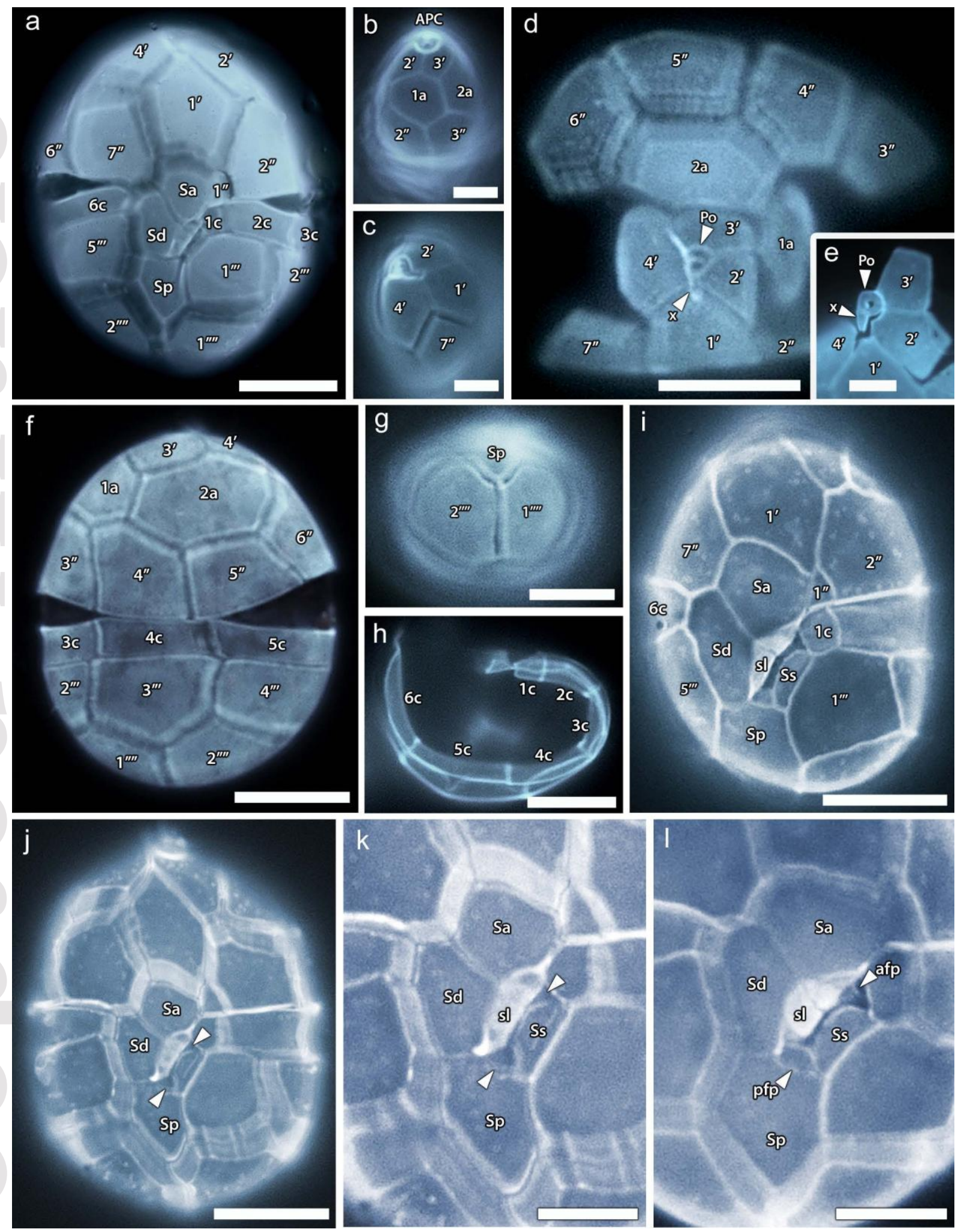

This article is protected by copyright. All rights reserved. 

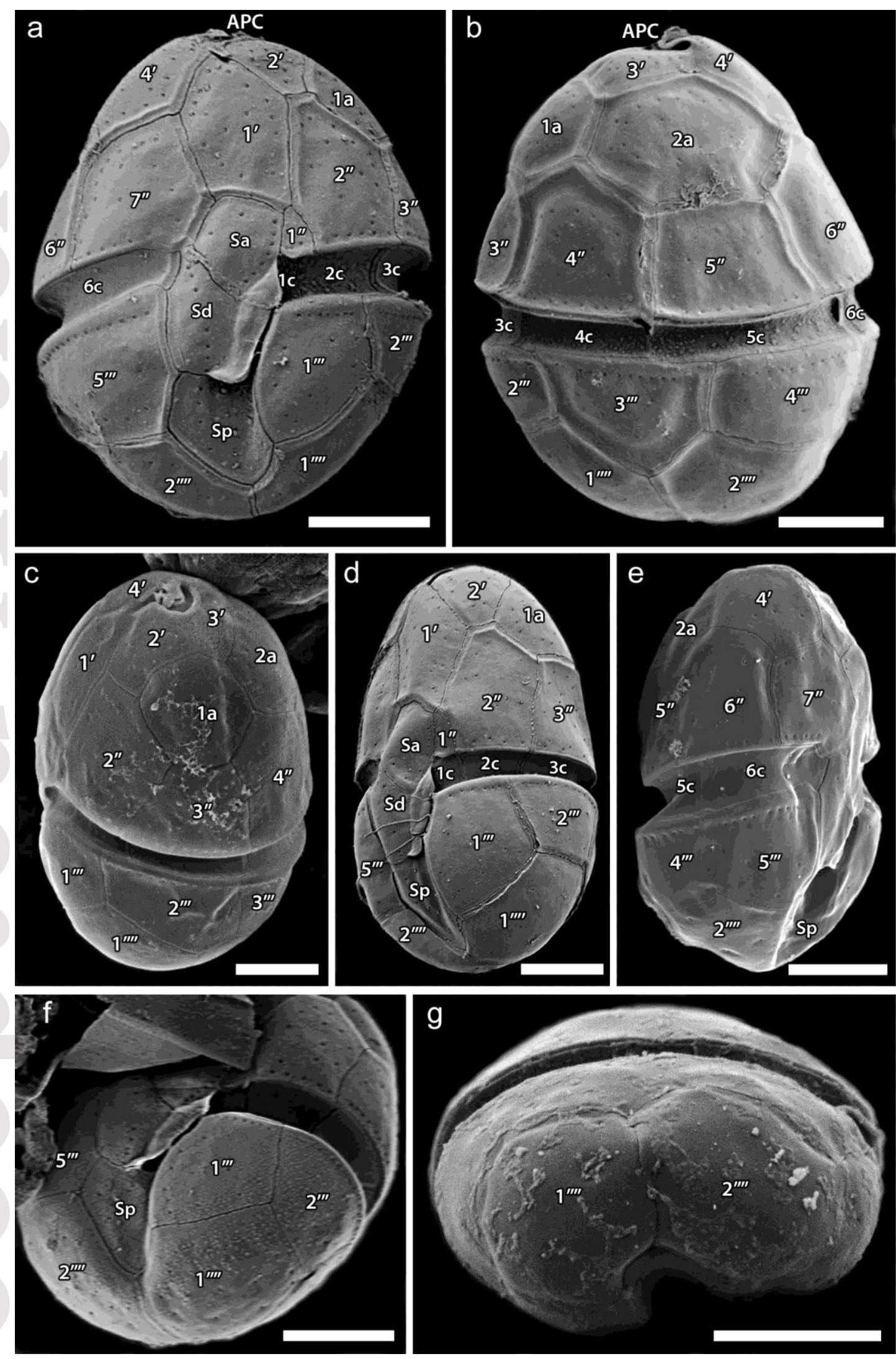

This article is protected by copyright. All rights reserved. 

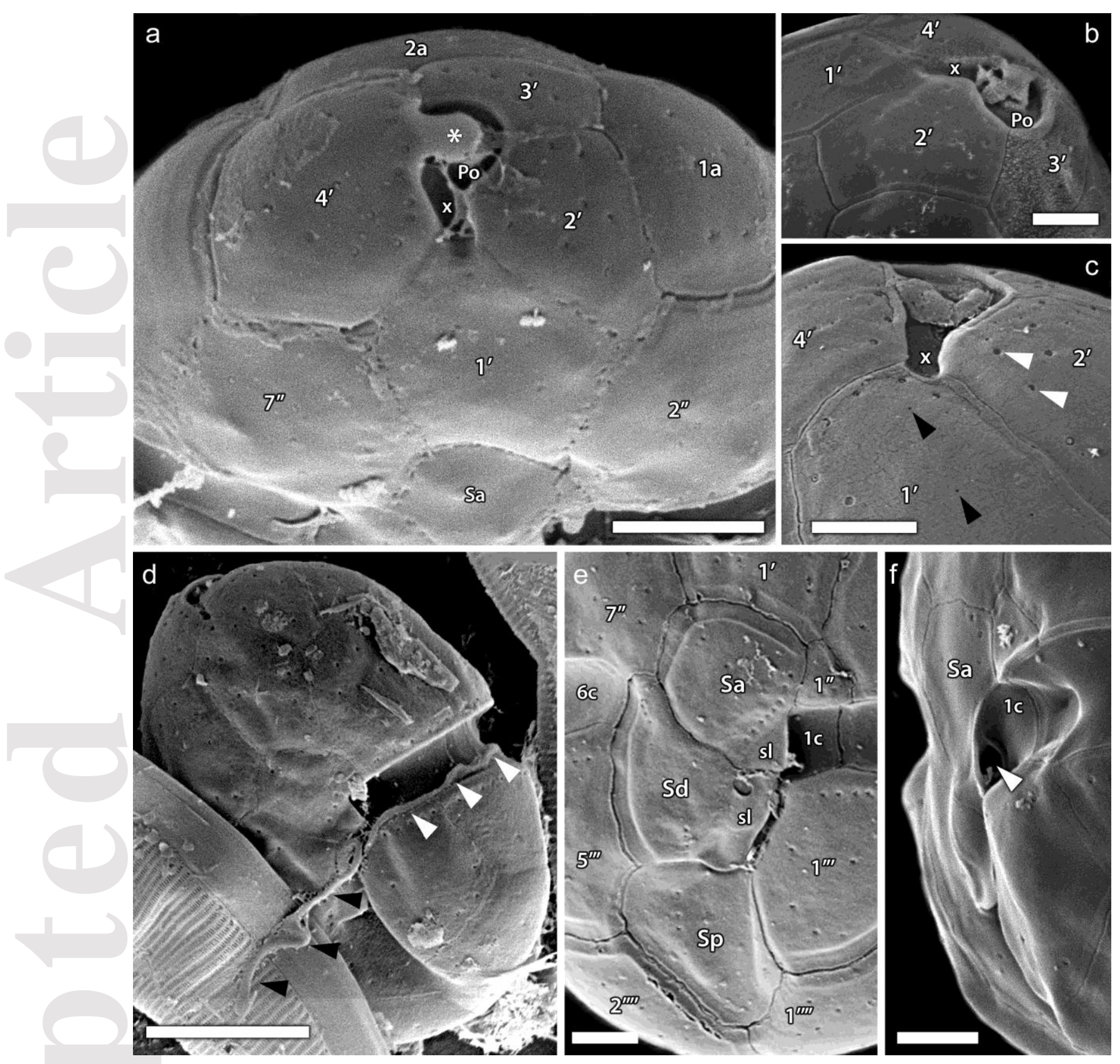

This article is protected by copyright. All rights reserved. 


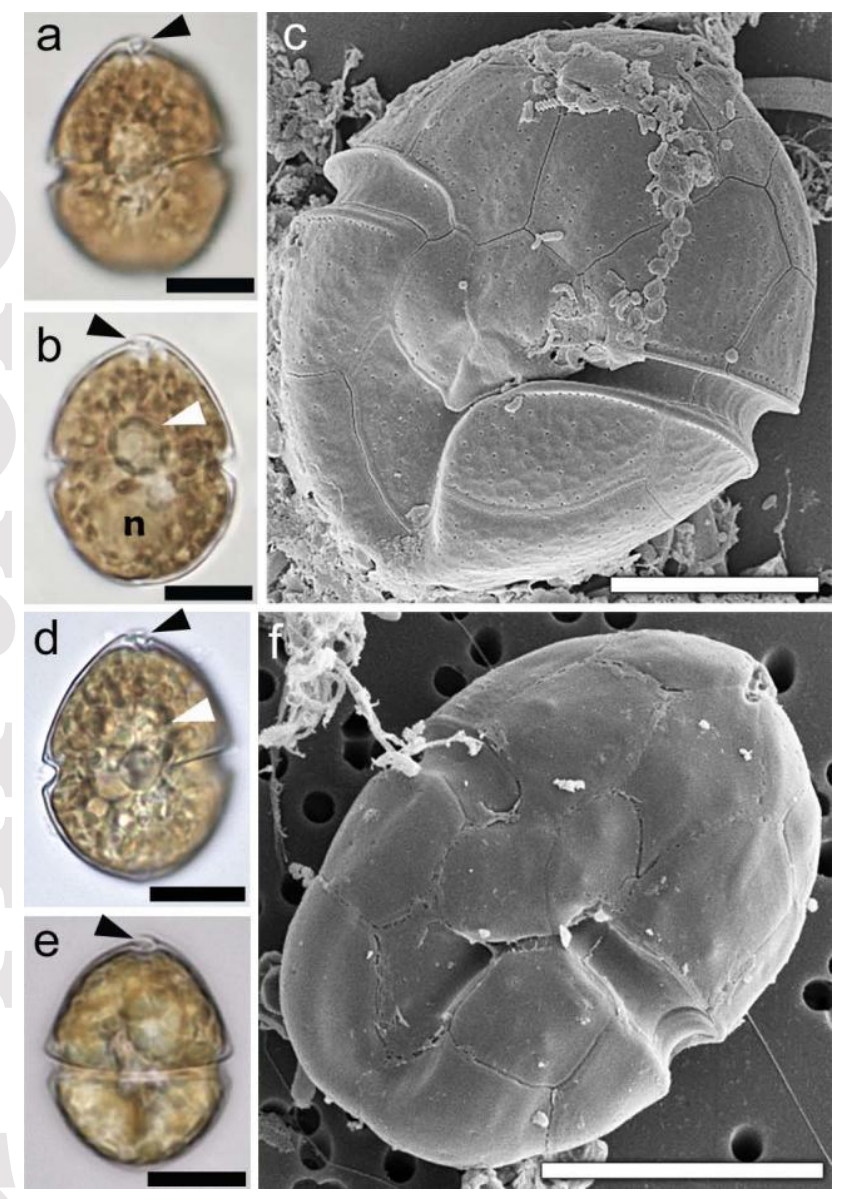

This article is protected by copyright. All rights reserved. 


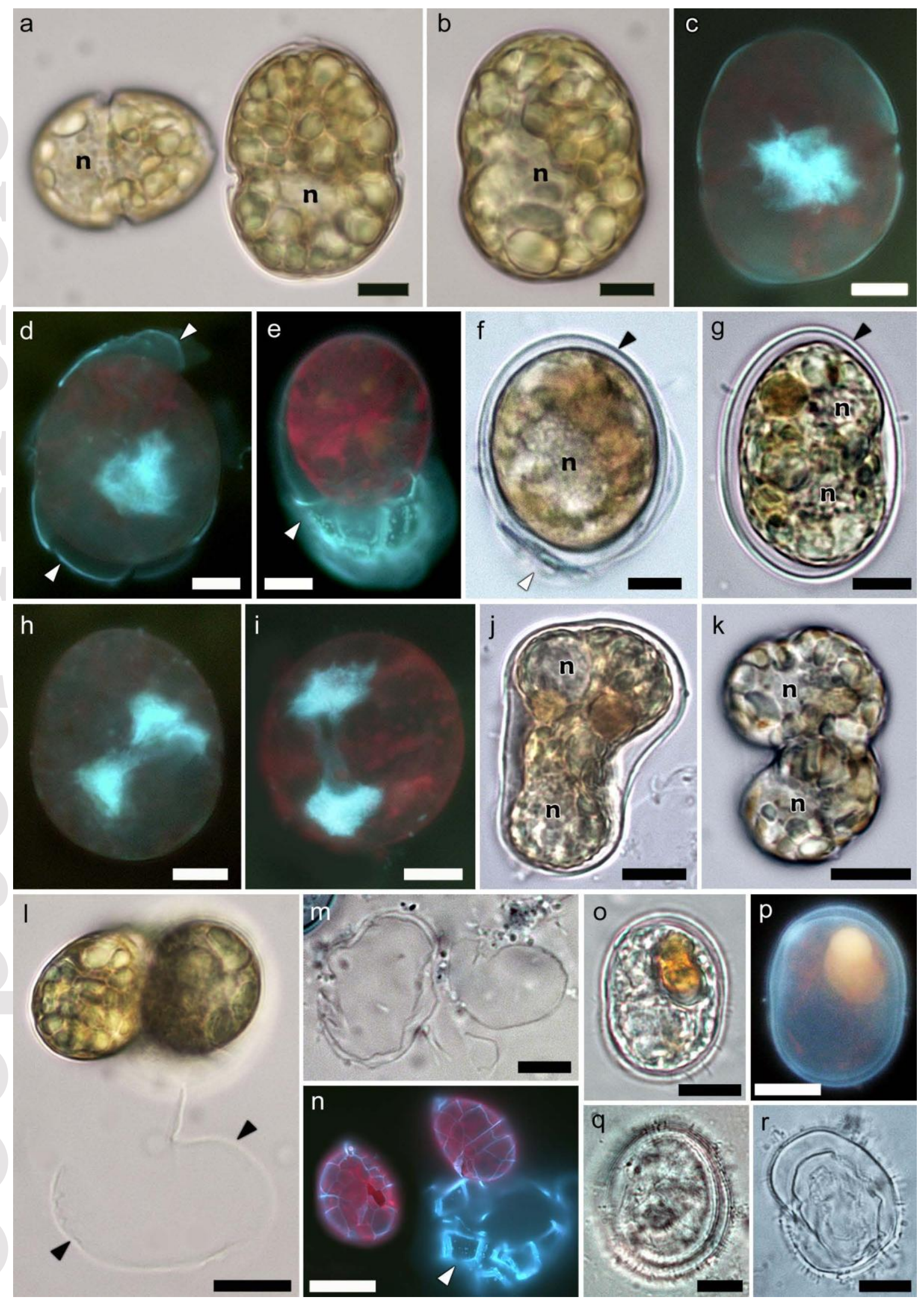

This article is protected by copyright. All rights reserved. 
a

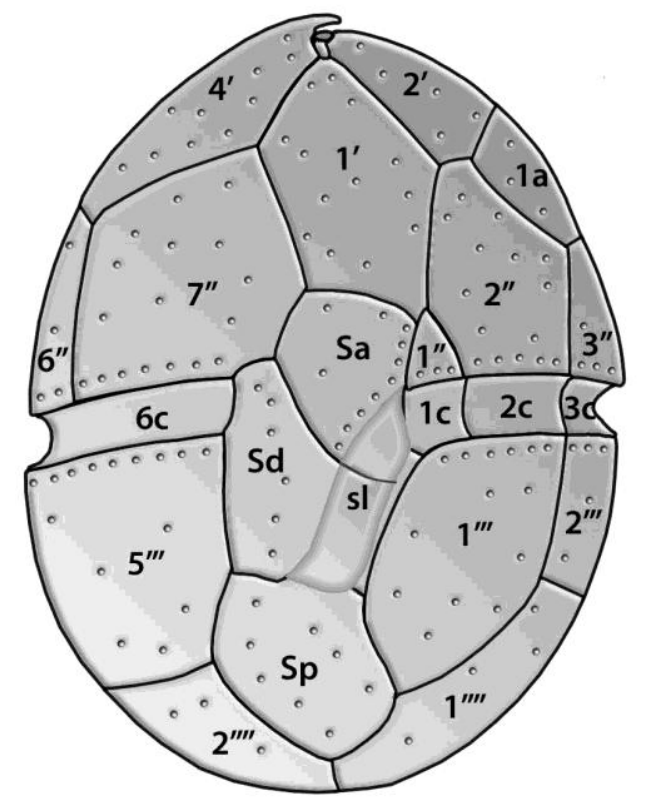

C

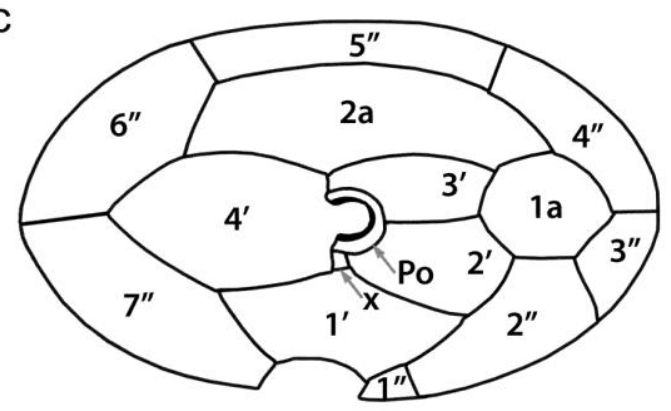

d

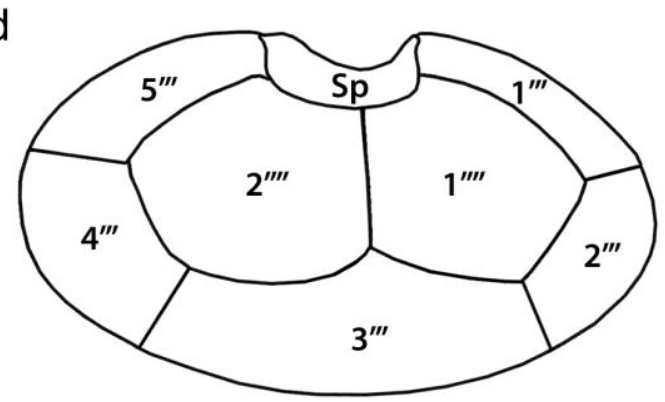

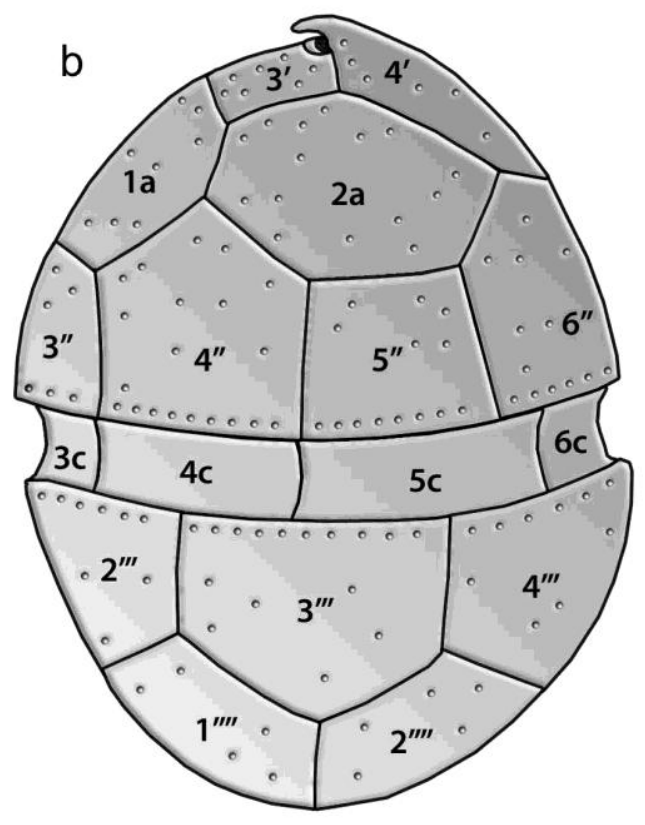

e

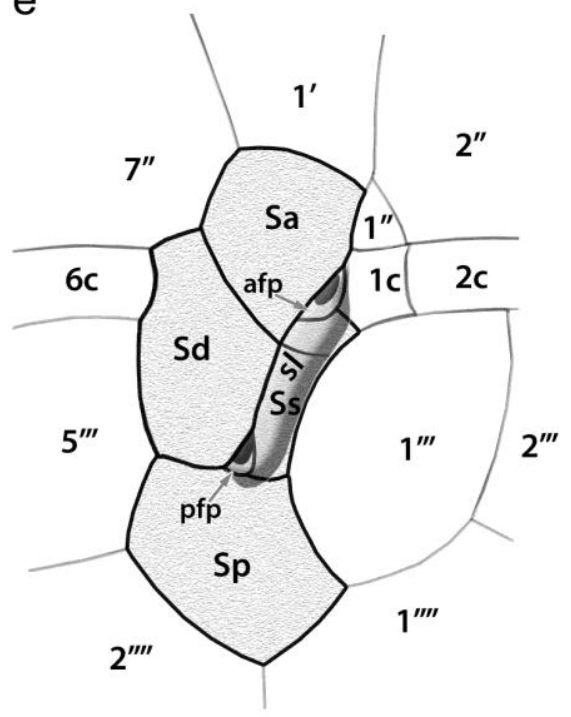




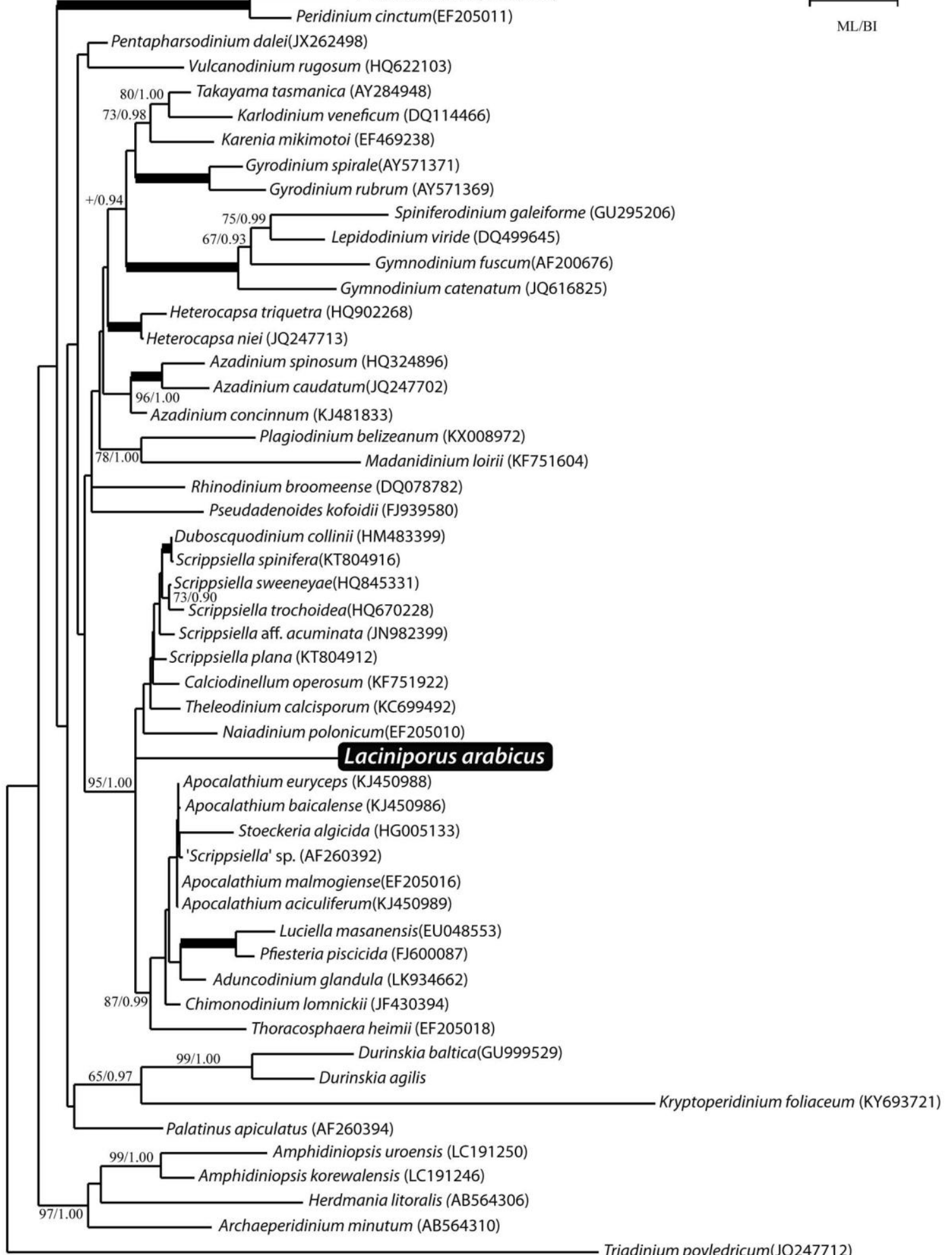

